\title{
The cell-cell junctions of mammalian testes: II. The lamellar smooth muscle monolayer cells of the peritubular wall are laterally connected by vertical adherens junctions-a novel architectonic cell-cell junction system
}

\author{
Lisa M. Domke ${ }^{1} \cdot$ Werner W. Franke ${ }^{1}$
}

Received: 9 August 2018 / Accepted: 20 November 2018 / Published online: 27 December 2018

(C) The Author(s) 2018

\begin{abstract}
The testes of sexually mature males of six mammalian species (men, bulls, boars, rats, mice, guinea pigs) have been studied using biochemical as well as light and electron microscopical techniques, in particular immunolocalizations. In these tissues, the peritubular walls represent lamellar encasement structures wrapped around the seminiferous tubules as a bandage system of extracellular matrix layers, alternating with monolayers of very flat polyhedral "lamellar smooth muscle cells" (LSMCs), the number of which varies in different species from 1 to 5 or 6 . These LSMCs are complete SMCs containing smooth muscle $\alpha$ actin (SMA), myosin light and heavy chains, $\alpha$-actinin, tropomyosin, smoothelin, intermediate-sized filament proteins desmin and/or vimentin, filamin, talin, dystrophin, caldesmon, calponin, and protein SM22 $\alpha$, often also cytokeratins 8 and 18. In the monolayers, the LSMCs are connected by adherens junctions (AJs) based on cadherin-11, in some species also with P-cadherin and/or E-cadherin, which are anchored in cytoplasmic plaques containing $\beta$-catenin and other armadillo proteins, in some species also striatin family proteins, protein myozap and/or LUMA. The LSMC cytoplasm is rich in myofilament bundles, which in many regions are packed in paracrystalline arrays, as well as in "dense bodies," "focal adhesions," and caveolae. In addition to some AJ-like end-on-end contacts, the LSMCs are laterally connected by numerous vertical AJ-like junctions located in variously sized and variously shaped, overlapping (alter super alterum) lamelliform cell protrusions. Consequently, the LSMCs of the peritubular wall monolayers are SMCs sensu stricto which are laterally connected by a novel architectonic system of arrays of vertical AJs located in overlapping cell protrusions.
\end{abstract}

Keywords Seminiferous tubules $\cdot$ Peritubular walls $\cdot$ Desmosomes $\cdot$ Hemidesmosomes $\cdot$ Smooth muscle cells $\cdot$ Adherens junctions (AJs)

This research article is dedicated to the memory of Professor Jörg Langowski (Ph.D.) of the German Cancer Research Center who died on May 06, 2017, as a glider pilot in an air accident. As head of the division "Biophysics of Macromolecules," Jörg has published - inter alia - a series of major contributions in the field of biophysics and molecular biology of cytoskeletal proteins.

Electronic supplementary material The online version of this article (https://doi.org/10.1007/s00441-018-2968-x) contains supplementary material, which is available to authorized users.

Werner W. Franke

w.franke@dkfz.de

Lisa M. Domke

1.domke@dkfz.de

1 Helmholtz Group for Cell Biology, German Cancer Research Center (DKFZ), Im Neuenheimer Feld 280, 69120 Heidelberg, Germany

\begin{tabular}{|c|c|}
\hline \multicolumn{2}{|c|}{ Abbreviations } \\
\hline $\mathrm{AJ}(\mathrm{s})$ & Adherens junction(s) \\
\hline ARVCF & $\begin{array}{l}\text { Armadillo repeat gene deleted in } \\
\text { velo-cardio-facial syndrome }\end{array}$ \\
\hline ASA & Alter super alterum \\
\hline $\mathrm{CDH}$ & Cadherin \\
\hline $\mathrm{CK}(\mathrm{s})$ & Cytokeratin(s) \\
\hline CLC & Cumulative literature collection \\
\hline ECM & Extracellular matrix \\
\hline ESM & Electronic supplementary materia \\
\hline IF & Intermediate-sized filament \\
\hline $\operatorname{LSMC}(\mathrm{s})$ & Lamellar smooth muscle cell(s) \\
\hline SLC(s) & Special literature collection(s) \\
\hline SMA & Smooth muscle $\alpha$-actin \\
\hline $\mathrm{SMC}(\mathrm{s})$ & Smooth muscle cell(s) \\
\hline
\end{tabular}




\section{Introduction}

In previous studies of mature mammalian testes, we had noted that the epithelium within the seminiferous tubules is fundamentally different from all other epithelia, including those of the testicular excurrent ducts. With respect to the major molecular and ultrastructural components in the mature and healthy seminiferous tubules, it has for example been found that in this stage, the Sertoli and germ cells

- do not contain any cytokeratin (CK) but only vimentin intermediate-sized filaments (IFs), often organized in bundles enriched in the perinuclear region (Franke et al. 1979, 1982b; see also Spruill et al. 1983; Paranko and Virtanen 1986; for further references, see Domke et al. 2014);

- do not contain desmosomes or desmosome-like structures, not even any desmosome-specific marker proteins or glycoproteins (Franke et al. 1982a; Domke et al. 2014; for a list of opposite reports and claims, see ESM, Table S1);

- do not contain E-cadherin (CDH1)-based but only Ncadherin (CDH2)-based adherens junctions (AJs; Franke et al. 1982a; Cyr et al. 1992, 1993; Newton et al. 1993; Byers et al. 1994; Domke et al. 2014; Domke 2018); and

- do not contain an apical zonula adhaerens but deep plasma membrane indentations in the apical plasma membranes of the Sertoli cells in which the spermatid heads are embedded (cf. Franke et al. 1978a).

On the other hand, we have recently found that the cells within the seminiferous tubules are connected with each other and with the germ cells by special—often very large-N-cadherin-based AJ-type junctions ("areae adhaerentes"), which in many regions are characterized by cytoplasmic AJ plaques containing $\alpha$ - and $\beta$-catenin, proteins p120 and p0071, as well as plakoglobin (Domke et al. 2014). Moreover, we have also discovered a very special form of Sertoli cell junctions, the cribelliform junctions ("areae cribelliformes"), which are characterized by groups of cytoplasm-to-cytoplasm channels of 5-7 nm cytoplasmic width which are laterally connected by short TJ- or AJ-type structures (Domke et al. 2014).

In our studies of the seminiferous tubules, we have also studied the very thin encasement structure, the "peritubular wall," consisting of layers of extracellular matrix (ECM) alternating with special cell monolayers which have been described for decades in numerous publications as "myofibroblasts," "myoid cells," "myoid layers of the tunica propria," "peritubular contractile cells," "lamina propria cells," "interlamellar cells," or "interlaminar cells" (e.g., Ross and Long 1966; Ross 1967; Fawcett et al. 1969; Dym and
Fawcett 1970; Böck et al. 1972; Hovatta 1972; Kormano and Hovatta 1972; Dym 1975; Hargrove et al. 1977; for further references see, e.g., ESM, CLC, and SLCs Nos. 1 and 2). As the complex peritubular wall structure so far had not been sufficiently analyzed and adequately characterized in molecular and ultrastructural terms, we decided to study the molecular composition as well as the cell and tissue architecture of the peritubular wall in diverse mammalian species.

\section{Material and methods}

\section{Tissues and cells}

Bovine tissue samples of freshly slaughtered animals were obtained in the regional slaughterhouse (Mannheim, Germany), murine tissue samples (rat and mouse), and guinea pig tissues from mature and sexually active animals kept in the Central Animal Laboratory of the German Cancer Research Center (Heidelberg, Germany; for details see Franke et al. 2006, 2015; Domke et al. 2014). Tissue specimens from 3-year-old boars (German landrace pigs) were provided by Dr. Heiner Niemann, head of the Institute of Farm Animal Genetics (Friedrich-LoefflerInstitute, Federal Research Institute for Animal Health, Mariensee, Germany) and fixed as described (Rickelt et al. 2011; Domke et al. 2014). Human tissue samples were obtained from surgical material taken and processed in compliance with the regulations of the Ethics Committees of the Universities of Heidelberg and Marburg (Germany; see also Franke et al. 2006, 2015; Domke et al. 2014). In particular, the following tissues were used: testis, testicular excurrent ducts, liver, intestine, tongue mucosa, esophagus, heart, bladder, and bovine muzzle.

Generally, the tissue samples were snap-frozen in isopentane, precooled in liquid nitrogen, and then stored at $-80{ }^{\circ} \mathrm{C}$ until use (see also the aforecited references). Cryosections of frozen tissue samples were used for immunofluorescence microscopy, immunoelectron microscopy, and analyses by SDS-polyacrylamide gel electrophoresis (SDSPAGE) of polypeptides, followed by immunoblotting ("Western blots"). Alternatively, the tissue samples were fixed at $4{ }^{\circ} \mathrm{C}$ with $2 \%$ or $4 \%$ formaldehyde, freshly prepared from paraformaldehyde in PBS, and then dehydrated in an ethanol series and finally embedded in paraffin.

\section{Antibodies}

The antibodies used in immunoblotting analyses of polypeptides separated by SDS-PAGE, immunofluorescence, and immunoelectron microscopy are listed in Tables 1 and 2 and in previous publications (e.g., Franke et al. 2013, 2015; Rickelt et al. 2011; Domke et al. 2014). 
Table 1 Results of immunofluorescence microscopy on peritubular wall cells (LSMCs) of mature bovine testis using antibodies to specific smooth muscle marker molecules

\begin{tabular}{|c|c|c|c|}
\hline Antigen & Antibodies used (type and source) ${ }^{1}$ & Relative intensity $^{2}$ & Reactions positive in other species examined \\
\hline \multirow[t]{2}{*}{ Smooth muscle $\alpha$-actin } & m (mcl, Progen Biotechnik, 61001) & ++ & Man, boar, rat, m, gp \\
\hline & rb (pcl, Abcam, ab5694) & ++ & Man, boar, rat, m, gp \\
\hline Myosin (smooth muscle; heavy chain) & m (mcl, Sigma-Aldrich, M7786) & ++ & Man, boar, rat, gp \\
\hline Myosin (smooth muscle; light chain 2) & rb (pcl, Cell Signalling, 3672) & ++ & Man, boar, rat, m, gp \\
\hline Myosin (skeletal and smooth muscle) & rb (pcl, Sigma-Aldrich, M7648) & + & Man, boar, rat, m, gp \\
\hline \multirow[t]{3}{*}{ Desmin } & m (mcl, Progen Biotechnik, 10519) & ++ & Man, boar, rat, m, gp \\
\hline & m (mcl, Dako, M0724) & ++ & Man, gp \\
\hline & rb (pcl, Progen Biotechnik, 10570) & ++ & Man, boar, rat, m, gp \\
\hline \multirow[t]{2}{*}{ Vimentin } & m (mcl, Progen Biotechnik, 65113) & ++ & Man, boar, rat, m, gp \\
\hline & gp (pcl, authors' laboratory*, 2A) & ++ & Man, boar, rat, m, gp \\
\hline \multirow[t]{2}{*}{ Smoothelin } & m (mcl, Millipore, MAB3242) & ++ & Man, boar, gp \\
\hline & rb (pcl, Abcam, ab204305) & ++ & Man, boar, rat, m, gp \\
\hline \multirow[t]{2}{*}{ Protein SM22 $\alpha$} & rb (pcl, Abcam, ab155272) & $(+)^{3}$ & No cross-reaction in LSMCs of other species \\
\hline & rb (pcl, Abcam, ab14106) & + & gp \\
\hline Calponin & m (mcl, Sigma-Aldrich, C2687) & ++ & Man, boar, rat, gp \\
\hline Caldesmon & rb (pcl, Abcam, ab32330) & + & Man, boar, rat, $\mathrm{m}$ \\
\hline \multirow[t]{2}{*}{$\alpha$-Actinin } & m (mcl, Sigma-Aldrich, A5044) & ++ & Man, boar, rat, m, gp \\
\hline & rb (pcl, Sigma-Aldrich, A2543) & ++ & Man, boar, rat, m, gp \\
\hline \multirow[t]{2}{*}{ Tropomyosin } & m (mcl, Sigma-Aldrich, T2780) & + & Man, boar, rat, m, gp \\
\hline & rb (pcl, Sigma-Aldrich, T3651) & + & Man, boar, rat, m, gp \\
\hline Talin & m (mcl, Sigma-Aldrich, SAB4200041) & ++ & Man, boar, rat, m \\
\hline Filamin A & rb (mcl, Abgent, AJ1299a) & ++ & Man, boar, rat, m, gp \\
\hline \multirow[t]{2}{*}{ Vinculin/metavinculin } & m (mcl, Sigma-Aldrich, V4505) & + & Man, boar, rat, m, gp \\
\hline & rb (pcl, Sigma-Aldrich, V4139) & + & Man, boar, rat \\
\hline Dystrophin & rb (pcl, Abcam, ab15277) & ++ & Man, boar, rat, m, gp \\
\hline
\end{tabular}

Control tissues used include excurrent ducts of the testis, bladder, tongue mucosa, intestine, and myocardium

* Original antibodies made in the authors' laboratory

${ }^{1}$ Abbreviations used for type and source of antibodies: gp guinea pig, m mouse, mcl monoclonal, pcl polyclonal, rb rabbit

${ }^{2}$ Symbols used for relative intensities: ++ high intensity, + moderate intensity

${ }^{3}$ Only a few preparations showed positive antibody reaction, maybe due to specific SM22 $\alpha$ isoforms

Primary antibodies were visualized with goat anti-mouse, goat anti-guinea pig, goat anti-rat, or goat anti-rabbit IgG $(\mathrm{H}+\mathrm{L})$ secondary antibodies conjugated to $\mathrm{Cy} 3$ (Dianova, Hamburg, Germany) or Alexa 488 (Invitrogen, Karlsruhe, Germany). Immunoblot analysis was performed with horseradish-peroxidase (HRP)-conjugated secondary antibodies (Dianova).

\section{Gel electrophoresis and immunoblotting}

Polypeptides of tissue samples were biochemically analyzed using SDS-PAGE and immunoblotting as described (Achtstaetter et al. 1986; Rickelt et al. 2010, 2011; Straub et al. 2011; Pieperhoff et al. 2012; Domke et al. 2014).

\section{Immunofluorescence microscopy}

Analyses by immunofluorescence microscopy were performed as described (see, e.g., Franke et al. 2006, 2015; Rickelt et al. 2011; Pieperhoff et al. 2012; Domke et al. 2014). The frozen tissue sections were mounted on glass slides (Thermo Fisher Scientific, Rockford, IL, USA) and shortly air-dried, followed by fixation for $10 \mathrm{~min}$ in a $20{ }^{\circ} \mathrm{C}$ cold methanol/acetone (1:1) mixture and subsequent air-drying. The fixed sections were rehydrated in PBS and incubated in PBS containing $0.1 \%$ Triton X100 for $4 \mathrm{~min}$, followed by two washing steps with PBS for $5 \mathrm{~min}$ and subsequent incubation with primary antibodies for a minimum of $1 \mathrm{~h}$.

Alternatively, the specimens were fixed for 6-8 $\mathrm{min}$ with $2 \%$ formaldehyde in PBS, freshly prepared from 
Table 2 Immunofluorescence microscopy reactions of further antibodies against cytoskeletal, junctional, and ECM marker molecules on LSMCs of the peritubular wall

\begin{tabular}{|c|c|c|}
\hline Antigen & Antibodies (type and source) ${ }^{1}$ & Relative intensity on bovine LSMCs ${ }^{2}$ \\
\hline$\alpha$-Actin & m (mcl, Progen Biotechnik, 651132) & + \\
\hline$\alpha$-Cardiac actin & m (mcl, Progen Biotechnik, 61075) & - \\
\hline$\alpha$-Skeletal/cardiac actin & m (mcl, Novus, NBP1-97725) & - \\
\hline Ankyrin-G & $\mathrm{m}(\mathrm{mcl} \text {, Invitrogen, } 33-8800)^{3}$ & + \\
\hline$\alpha$-E-catenin & m (mcl, Thermo Fisher Scientific, 13-9700) & + \\
\hline \multirow[t]{2}{*}{$\beta$-Catenin } & $\mathrm{rb}(\mathrm{mcl}$, Abcam, ab32572) & + \\
\hline & m (mcl, BD Transduction Laboratories, 610154) & + \\
\hline Cadherin-1 (E-cadherin) & m (mcl, Transduction Laboratories, 610182) & + \\
\hline \multirow[t]{2}{*}{ Cadherin-2 (N-cadherin) } & rb (pcl, QED Biosciences, 42031) & sd \\
\hline & m (mcl, Transduction Laboratories, 610921) & $\mathrm{sd}$ \\
\hline Cadherin-3 (P-cadherin) & rat (mcl, Thermo Fisher Scientific, 13-2000Z) & + \\
\hline Cadherin-5 (VE-cadherin) & rb (pcl, Cayman Chemical Company, 160840) & - \\
\hline Cadherin-6 (K-cadherin) & m (mcl, Progen Biotechnik, 16111) & - \\
\hline \multirow[t]{3}{*}{ Cadherin-11 (OB-cadherin) } & m (mcl, Progen Biotechnik, 16113) & ++ \\
\hline & m (mcl, Thermo Fisher Scientific, 32-1700) & ++ \\
\hline & rb (pcl, Thermo Fisher Scientific, 71-7600) & ++ \\
\hline Calicin & m (mcl, authors' laboratory*) & - \\
\hline Caveolin-1 & rb (mcl, Cell Signaling, 3267) & ++ \\
\hline \multirow[t]{2}{*}{ Claudin-3 } & rb (pcl, Thermo Fisher Scientific, 34-1700) & - \\
\hline & $\mathrm{rb}(\mathrm{pcl}, \mathrm{Abcam}, \mathrm{ab} 15102)$ & - \\
\hline Claudin-4 & m (mcl, Thermo Fisher Scientific, 32-9400) & - \\
\hline \multirow[t]{2}{*}{ Claudin-5 } & m (mcl, Thermo Fisher Scientific, 35-2500) & - \\
\hline & m (mcl, Thermo Fisher Scientific, 18-7364) & - \\
\hline \multirow[t]{2}{*}{ Claudin-11 } & rb (pcl, Thermo Fisher Scientific, 36-4500) & - \\
\hline & rb (pcl, Abcam, ab53041) & - \\
\hline Collagen IV & rb (pcl, Progen Biotechnik, 10760) & + \\
\hline Procollagen & m (mcl, Millipore, MAB1913) & + \\
\hline Cylicin I & gp (pcl, authors' laboratory*) & - \\
\hline Cylicin II & gp (pcl, authors' laboratory*) & - \\
\hline Cytokeratin 8 & m (mcl, Progen Biotechnik, 65138) & $(+)^{4}$ \\
\hline \multirow[t]{2}{*}{ Cytokeratin 18} & m (mcl, Progen Biotechnik, 10500) & $(+)^{4}$ \\
\hline & m (mcl, authors' laboratory*, cl. 174.14.11) & $(+)^{4}$ \\
\hline Desmocollin 2 & rb (pcl, Progen Biotechnik, 610120) & - \\
\hline Desmoglein $1+2$ & m (mcl, Progen Biotechnik, 61002) & - \\
\hline \multirow[t]{2}{*}{ Desmoglein 1} & m (mcl, Thermo Fisher Scientific, 32-6000) & - \\
\hline & m (mcl, Progen Biotechnik, 651110) & - \\
\hline \multirow[t]{2}{*}{ Desmoglein 2} & rb (pcl, Progen Biotechnik, 610121) & - \\
\hline & m (mcl, Thermo Fisher Scientific, 32-6100) & - \\
\hline Desmoglein 3 & m (mcl, Thermo Fisher Scientific, 32-6300) & - \\
\hline Desmoplakin $1+2$ & m (mcl, Progen Biotechnik, 65146) & - \\
\hline Drebrin & $\mathrm{m}\left(\mathrm{mcl}\right.$, Progen Biotechnik, 612128) ${ }^{5}$ & + \\
\hline EpCAM & m (mcl, Progen Biotechnik, 61004) & - \\
\hline Fibronectin & m (mcl, Sigma-Aldrich) & + \\
\hline HD 220/233 & m (mcl, kindly provided by K. Owaribe, University of Nagoya, Japan) & - \\
\hline Integrin $\alpha 6$ & rat (pcl, Progen Biotechnik, 10709) & + \\
\hline Integrin $\beta 4$ & rb (mcl, Abcam ab133682) & + \\
\hline \multirow[t]{2}{*}{ Myozap } & m (mcl, Progen Biotechnik, 651169) & + \\
\hline & gp (pcl, authors' laboratory*, 2A) & + \\
\hline
\end{tabular}


Table 2 (continued)

\begin{tabular}{|c|c|c|}
\hline Antigen & Antibodies (type and source) ${ }^{1}$ & Relative intensity on bovine $\mathrm{LSMCs}^{2}$ \\
\hline \multirow[t]{2}{*}{ Laminins } & rb (pcl, Progen Biotechnik, 10765) & ++ \\
\hline & rb (pcl, Sigma-Aldrich, L9393) & ++ \\
\hline Protein LUMA & gp (pcl, authors' laboratory*, 2A) & + \\
\hline 1/s Afadin & rb (plc, Sigma-Aldrich, A0224) & - \\
\hline LYVE-1 & rb (pcl, Acris, DP3500PS) & - \\
\hline Myomesin (Myom-2) & $\mathrm{rb}$ (pcl, Acris, AP01485PU-N) & - \\
\hline PE-CAM (CD 31) & m (mcl, Thermo Fisher Scientific, 37-0700) & - \\
\hline \multirow[t]{3}{*}{ Protein PERP } & m (mcl, authors' laboratory*, 26.3.30.) & - \\
\hline & m (mcl, authors' laboratory*, 8.2.9.) & - \\
\hline & gp (pcl, authors' laboratory*, 4A) & - \\
\hline Plakoglobin & m (mcl, Progen Biotechnik, 65105) & - \\
\hline Plakophilin 1 & m (mcl, Progen Biotechnik, 65160) & - \\
\hline Plakophilin 2 & m (mcl, Progen Biotechnik, 651101) & - \\
\hline Plakophilin 3 & m (mcl, Progen Biotechnik, 651113) & - \\
\hline \multirow[t]{3}{*}{ Plectin } & gp (pcl, Progen Biotechnik, GP21) & - \\
\hline & rb (pcl, Abcam, ab83497) & - \\
\hline & m (mcl, Novus Biologists, NB120-11220) & - \\
\hline \multirow[t]{2}{*}{ Podoplanin } & m (mcl, Acris, DM3500P) & - \\
\hline & m (mcl, Dako, M3619) & - \\
\hline Protein p120 & m (mcl, BD Transduction Laboratories, 610134) & sd \\
\hline \multirow[t]{2}{*}{ Protein p0071 } & m (mcl, Progen Biotechnik, 651165) & sd \\
\hline & gp (pcl, Progen Biotechnik, GP71) & sd \\
\hline \multirow[t]{2}{*}{ Striatin $^{6}$} & m (mcl, BD Transduction Laboratories, 610838) & - \\
\hline & gp (pcl, authors' laboratory*) & - \\
\hline \multirow[t]{2}{*}{ Tetraspanin (CD151) } & m (mcl, Acris, SM1209P) & - \\
\hline & rb (plc, Abcam, ab185684) & - \\
\hline Troponin $\mathrm{T}$ & m (mlc, Sigma-Aldrich, T6277) & - \\
\hline
\end{tabular}

*Original antibodies made in the authors' laboratory

${ }^{1}$ Abbreviations used for type and source of antibodies: gp guinea pig, m mouse, mcl monoclonal, pcl polyclonal, rb rabbit

${ }^{2}$ Symbols used for relative intensities: ++ high intensity, + moderate intensity, - no reaction, sd significance not decidable yet

${ }^{3}$ For a review, see Bennett and Healy (2009)

${ }^{4}$ The antibodies to cytokeratin 8 and/or 18 used are only positive on bovine and boar PW-LSMCs

${ }^{5}$ The antibodies used have been previously described: Peitsch et al. (1999, 2001, 2005)

${ }^{6}$ Striatin and proteins of the striatin family (Franke et al. 2015)

paraformaldehyde, before cells were permeabilized with $0.1 \%$ or $0.2 \%$ saponin in PBS for $5 \mathrm{~min}$, followed by two washing steps in PBS for $5 \mathrm{~min}$ each, and incubation with the specific primary antibodies in PBS, followed by three washing steps (5 min each) in PBS. Samples were then exposed to the specific secondary antibodies conjugated with fluorochromes for 30-60 min. In addition, nuclear chromatin was counterstained using DAPI (Serva, Heidelberg, Germany; 1:10,000 dilution) along with the secondary antibodies. Excess antibodies and antibodies not stably bound were removed by three washes with PBS (5 min each). Subsequently, specimens were rinsed in distilled water, dehydrated in ethanol, and mounted in
FluoromountG (Southern Biotech, Birmingham, AL, USA).

Immunofluorescence microscopic and phase contrast images were taken with an Axiophot II photomicroscope (Carl Zeiss, Jena, Germany), equipped with an AxioCam HR (Carl Zeiss), or with a confocal laser scanning microscope, a Zeiss LSM 800 instrument. Images were partially combined using a Tile scan tool (ZEN 2012 microscope software, version 8.1, Carl Zeiss Microscopy $\mathrm{GmbH}$ ). For immunofluorescence microscopy of paraffin-embedded tissue samples, the sections were deparaffinized and prepared for antigen-retrieval treatment according to standard protocols (Shi et al. 1991; Vlahova et al. 2012; see also Domke 2018). 

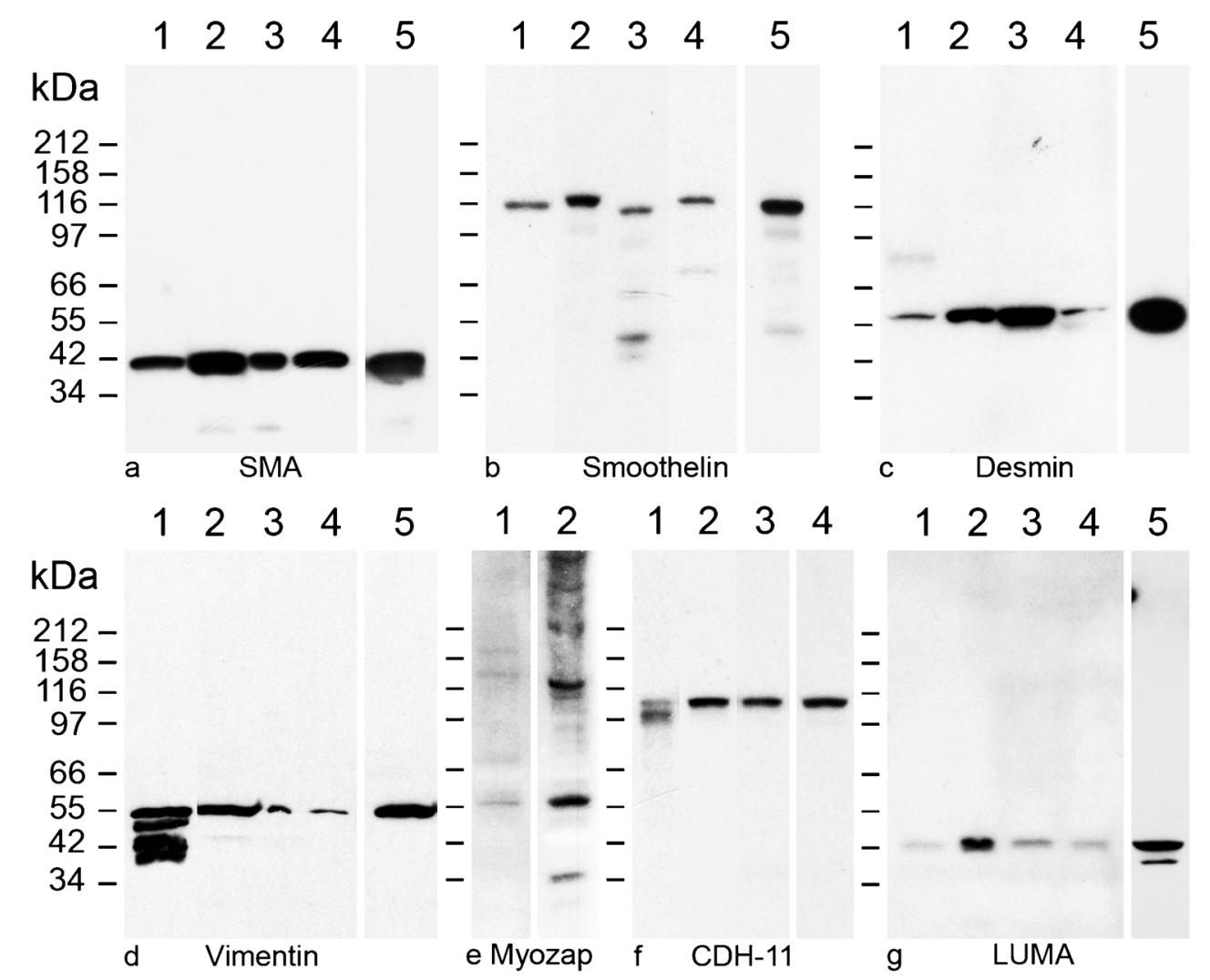

Fig. 1 Identification of proteins by SDS-PAGE of protein lysates in dissected tissue samples of mammalian testes and immunoblotting with specific antibodies (apparent molecular weights are indicated in $\mathrm{kDa}$ on the left margin). a Antibodies against smooth muscle $\alpha$-actin (SMA) show positive reactions in tissues of the seminiferous tubules of human (lane 1), bovine (lane 2), porcine (lane 3), and rat (lane 4) testis as well as in bovine bladder (lane 5). b Similarly, smoothelin is seen in these seminiferous tubules (lanes 1-4) and in bovine bladder (lane 5). c Desmin is detected in all testicular tissues (lanes $1-4$; here a lysate from cultured murine HL-1 cells, i.e., of cardiomyocyte origin, is shown in lane 5 for comparison). d Vimentin as a component of Sertoli, peritubular wall, and

\section{Electron and immunoelectron microscopy}

For electron and immunoelectron microscopy, previously published protocols were used (e.g., Langbein et al. 2002; Franke et al. 2006; Domke et al. 2014). For immunoelectron microscopy, cryostat sections of frozen tissue samples were fixed in $2 \%$ formaldehyde in PBS for 6-8 min and washed with PBS and incubated in $50 \mathrm{mM} \mathrm{NH}_{4} \mathrm{Cl}$ in PBS $(w / v)$ twice for $5 \mathrm{~min}$ each, followed by partial permeabilization with $0.1 \%$ saponin in PBS (3-4 min). Specimens were incubated with primary antibodies for $3 \mathrm{~h}$. After three washing steps, the samples were exposed to secondary antibodies conjugated with $1.4 \mathrm{~nm}$ gold particles (Nanoprobes, Yaphank, NY, USA) overnight at $4{ }^{\circ} \mathrm{C}$. In most cases, silver enhancement of gold particles was performed, using the HQ Silver Enhancement Kit from Biotrend (Köln, Germany) for various periods of time (5, 7, or $9 \mathrm{~min}$ ) after fixation with $2.5 \%$ glutardialdehyde in PBS for $30 \mathrm{~min}$ at $4{ }^{\circ} \mathrm{C}$ (for subsequent treatment see the references quoted interstitial cells is present in all testicular tissue lysates (lane 1, human; lane 2, bovine; lane 3, rat; lane 4, mouse) as well as in cultured human SV80 cells of mesenchymal origin (lane 5) added as control protein preparation. e Protein myozap (ca. $54 \mathrm{kDa}$ ) is present in testicular tissue of seminiferous tubules (lane 1, human) and excurrent ducts (lane 2, boar). f Cadherin-11 (CDH-11) is identified in the tissues of seminiferous tubules of human (lane 1), bull (lane 2), and boar (lane 3) as well as in excurrent duct tissues (e.g., lane 4, boar). g Protein LUMA (ca. $45 \mathrm{kDa}$ ) is present in the tissues of human (lane 1), bovine (lane 2), porcine (lane 3), and rat (lane 4) testis as well as in human HaCaT keratinocytes (lane 5)

above). Electron micrographs were taken at $80 \mathrm{kV}$ in an EM 10 (Carl Zeiss) instrument. In addition, series of (up to 30) coaxial or sagittal thin sections across the seminiferous tubule structures were evaluated in tile scans and after serial reconstruction of the electron micrographs used for visualization and tomography arrangements.

\section{Results}

\section{Biochemical identifications of cytoskeletal and junctional proteins and glycoproteins}

Beginning with the basal lamina of the testicular seminiferous tubules, we have studied the peritubular wall cell monolayers of diverse mammalian species using the adjacent epithelia of the excurrent ducts and various other tissues (intestine, liver, bladder, esophagus, tongue mucosa, heart, and bovine 

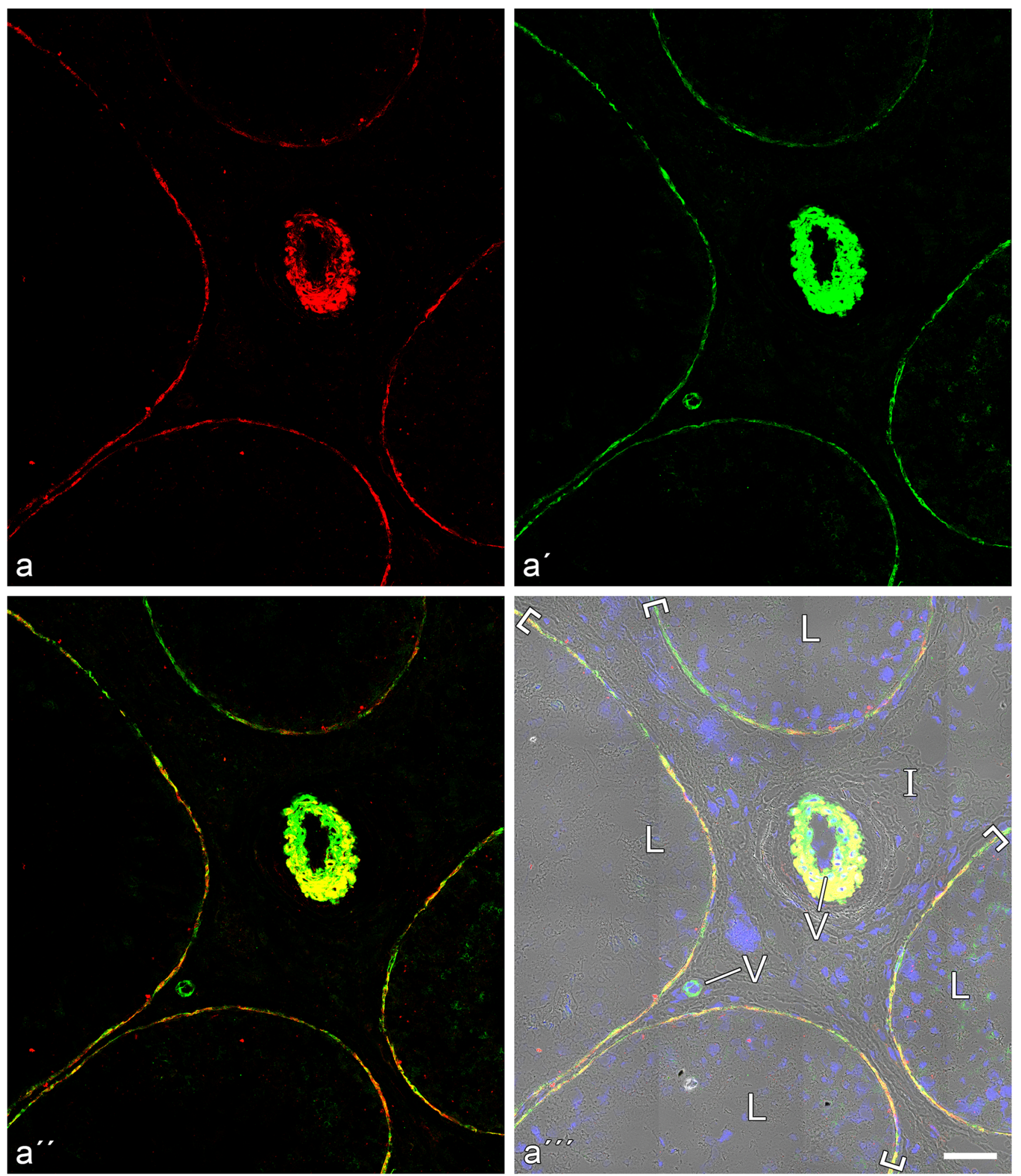

Fig. 2 Tile scan arrangement of images showing double-label immunofluorescence microscopy of fast-frozen bull testis tissue presenting a cryotomy cross section through seminiferous tubules (L, lumen) as well as blood vessels $(\mathrm{V})$ after reactions with monoclonal mouse antibodies to smoothelin (a, a", a"'; red) and rabbit antibodies to desmin (a'-a"'; green). Colocalization (yellow merge color) of both smooth muscle marker proteins is seen in relatively thin peritubular wall structures (brackets)

around the seminiferous tubules and in the perivascular smooth muscle cell layer of certain blood vessels ( $\mathrm{V}$, the very small vessel in the lower left region is negative for smoothelin and maybe negative or very low with respect to SMC differentiation) in the interstitial space (I). Images are shown on optical phase contrast background in a"'. Nuclei have been stained blue with DAPI (a"'). Bar $50 \mu \mathrm{m}$ 
muzzle) as controls. The specificity and sensitivity of the antibodies used have been examined by SDS-PAGE of polypeptides present in lysates from microdissected tissue samples, followed by immunoblotting. Some exemplary results are presented in Fig. 1 of the present report as well as in Fig. 1 of Domke et al. (2014). In this previous publication, the absence of reactions as negative controls is shown for $\mathrm{N}$-cadherin in the SDS-PAGE results of Fig. 1b, lanes 3, 5, and 7, i.e., for excurrent ducts of bull, boar, and mouse. Correspondingly, in Fig. 1d of that report, the absence of E-cadherin is shown for seminiferous tubules of testes from bull, boar, and mouse in lanes 2, 4, and 6. In contrast, E-cadherin is absent in the seminiferous tubule-enriched tissue of lanes $2-5$ of Fig. 1e, i.e., for bovine, rat, mouse, and human testes. Absolute negativity for desmoplakin is shown for seminiferous tubules of bull, rat, mouse, and human testes (lanes 2-5 of Fig. 1h), and the corresponding negative reactions for desmoglein Dsg-2 are seen in lanes $2-5$ of Fig. 1i). In the present publication, our results concerning the molecular composition are essentially identical in the six species analyzed (human, bovine, porcine, guinea pig, rat, and mouse).

\section{The basal lamina of the seminiferous epithelium}

In all six species examined, the basal plasma membrane of the seminiferous epithelium is different from those of other epithelia, including the testicular excurrent ducts (for opposite claims in the literature see, e.g., Wrobel et al. 1979): It does not reveal any hemidesmosomal structures and marker molecules such as the integrin $\alpha 6 / \beta 4$ complex, protein HD230 (bullous pemphigoid antigen, BPA 230), and tetraspanin CD151 (see, e.g., Owaribe et al. 1990, 1991; Sonnenberg et al. 1991; Uematsu et al. 1994; Sterk et al. 2000; Koster et al. 2003; see also ESM, SLC No. 7). The significance of these negative results in the seminiferous tubule epithelia of all species studied has been controlled by findings of hemidesmosomal structures and positive immunostaining of hemidesmosomal marker molecules in all E-cadherin-positive epithelial cells examined, including those of the specific excurrent ducts (see, e.g., ESM, Fig. S1).

In all six species, the basal lamina is well developed. In bovine testis, it shows in certain regions numerous, up to 2.5 - $\mu \mathrm{m}$-deep indentations into the Sertoli cells, often in almost regular patterns (lateral distances ca. 2-3 $\mu \mathrm{m}$; for electron microscopic examples see, e.g., Fig. 14; see also Wrobel et al. 1979). Such indentations have also been noted, though at lower frequency, in the basal lamina of human and porcine seminiferous tubules (for human testes see, e.g., Chakraborty et al. 1976). Moreover, several types of laminins are also generally found in close association with the Sertoli cell basal plasma membrane as well as with the peritubular wall layers and, together with integrins, fibronectin, collagen IV, and other collagens, shall be subject of a following special publication (for a
Fig. 3 Higher magnification of double-label immunofluorescence microscopy of cryotomy sections through frozen bull testis tissue (as in Fig. 2), showing that in the LSMC layers of the peritubular wall (brackets), smoothelin (a, a", a"', b, b", b"'; red; monoclonal mouse antibodies) and desmin (a', a"', b'-b"'; green; rabbit antibodies) colocalize in some regions (yellow merge color, with phase contrast background in a"', b"') but clearly not in all. At even higher magnification (b-b"'), another region is shown in which the local differences of both smooth muscle proteins are extended and many fibrils are seen in different orientations - some longitudinal, some in almost cross-striated appearance. L lumen, I interstitial space. Bars $20 \mu \mathrm{m}$

special electron microscopy study of localizations of ECM molecules see, e.g., Yazama et al. 1997; see also Vogl et al. 1993).

\section{The peritubular wall, a bandage structure of very flat smooth muscle cell monolayers alternating with ECM layers: immunofluorescence microscopy of contractile, cytoskeletal, and cell-cell junctional molecules}

In the frozen sections used for immunofluorescence microscopy, the smooth muscle cells (SMCs) of the peritubular wall appear - for the most part — as broad, flattened lamellae, hence collectively classified as lamellar SMCs (LSMCs), which are organized as bandages of monolayers alternating with ECM layers (cf., e.g., Leeson and Leeson 1963; De Kretser et al. 1975; Bustos-Obregon 1976; Wrobel et al. 1979; Maekawa et al. 1996). These bandages of one or several tightly packed LSMC-ECM layer pairs are closely wrapped around the specific seminiferous tubules and thus are especially well demonstrable in cross sections of these tubules. In such cross sections and in series of combinations of such sections, these LSMCs have been characterized by immunofluorescence microscopy, using antibodies specific for SMC marker proteins such as smoothelin, desmin, vimentin, smooth muscle $\alpha$-actin (SMA), light, and heavy chains of smooth muscle myosin, filamin, talin, dystrophin, and vinculin (for results and the specificities of the reagents used, see Tables 1 and 2). Some LSMC type-specific examples of these results are mentioned in Figs. 2, 3, 4, 5, and 6 and Table 1, and in ESM, Figs. S2 and S3. Table 2 presents a list of SMC-typical marker molecules identified as constituents of the peritubular wall LSMCs of mammalian testes or found absent from these cells (for relevant SMC biology, see references of ESM, SLC No. 3a).

As recent research results on the regulation of the synthesis of SMC proteins have indicated that for certain tissues such as vascular SMCs, smoothelin isoform B (ca. $110 \mathrm{kDa}$; see also Fig. 1b) is one of the most sensitive and specific SMC marker molecules (for review, see e.g., van Eys et al. 2007); we have frequently used smoothelin as a major SMC reference protein. Immunofluorescence microscopy using frozen sections of testes shows specific reactions with SMCs of blood vessel walls 

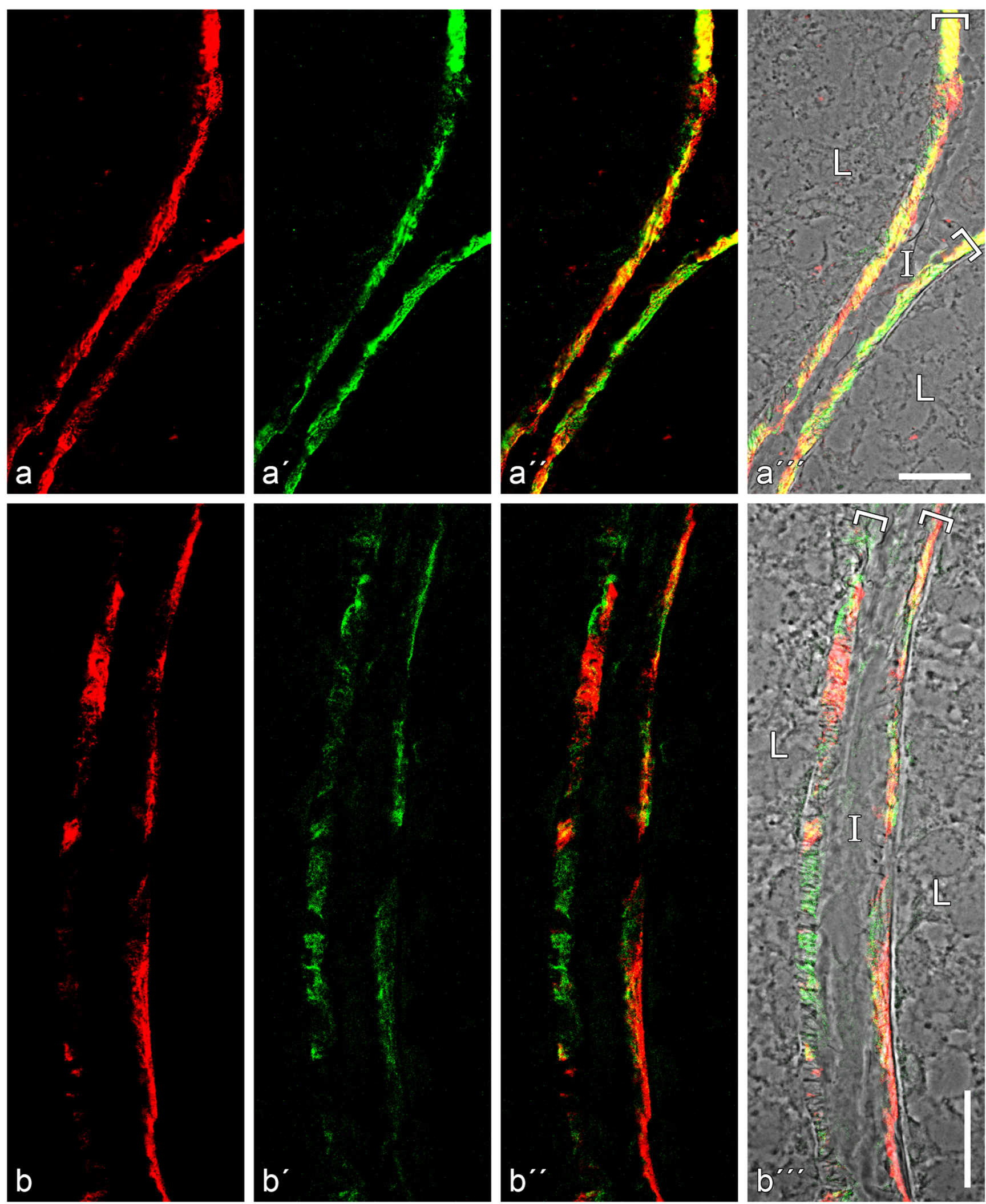

and the SMCs of the rather thin peritubular walls (for smoothelin and desmin in bovine testes, see e.g., Figs. 2, 3, and 4). At higher magnification (Fig. 3), one can distinguish distinct desmin- and/or smoothelin-containing structures and regions in the same cells. Figure 4 presents similar positive reactions in such cells for the intermediate-sized filament (IF) 

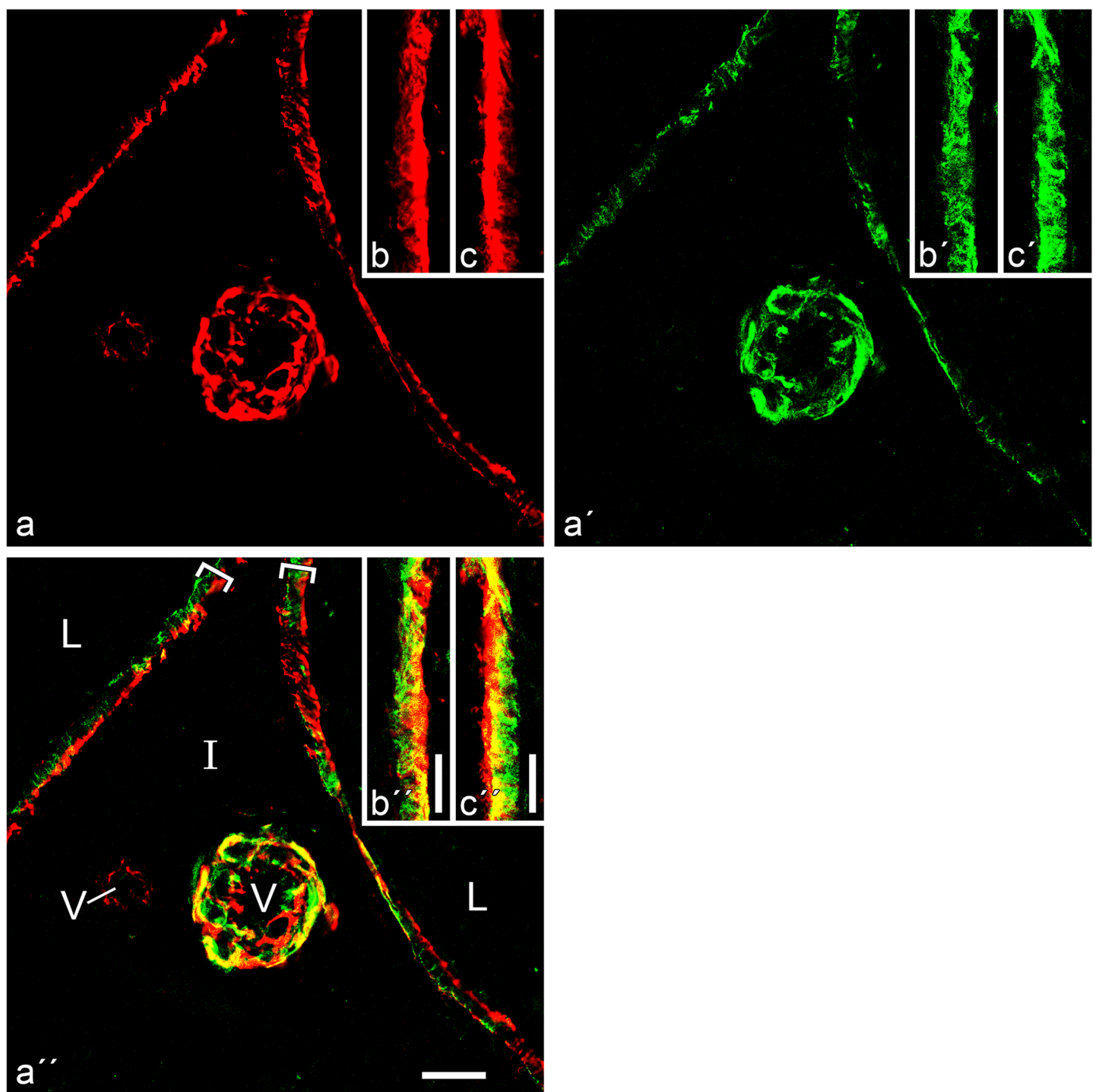

Fig. 4 Double-label immunofluorescence microscopy of a cryotomy cross section through walls of seminiferous tubules (L, lumen) and blood vessels $(\mathrm{V})$ in frozen bull testis tissue after reactions with monoclonal mouse antibodies against smooth muscle $\alpha$-actin (SMA; a, a"; red) and rabbit antibodies to desmin (a'-a"; green). Note that in the peritubular SMC layers (a"; brackets) as well as in the perivascular (V, vessel), SMC colocalization regions are seen (yellow merge color) next to others which

protein desmin and the myofilament marker SMA in the SMCs of both the blood vessels and the peritubular walls. Finally, two smooth muscle myofilament markers, SMA and smooth muscle myosin, are shown in Fig. 5 on a section through the peritubular wall of a human person of advanced age in which this wall is thicker and the LSMC layers appear

are specific for either SMA or desmin. Note also in the interstitial region (I) a small vessel (left V) which here is positive only for SMA (b', c'). The inserts (b-b", c-c") show at higher magnification regional localization and orientation differences of protein immunostainings in different peritubular wall cell layers or intercepts. Bars $20 \mu \mathrm{m}$ (a-a"), $10 \mu \mathrm{m}$ (bb", c-c")

to be separated by more ECM material. As another typical example showing the LSMC character, Fig. 6 presents double-label immunostaining of filamin A and SMA.

Essentially, all SMC-typical components which are listed in Table 1 have been localized to peritubular wall LSMCs by controlled immunofluorescence microscopy, in comparison with 

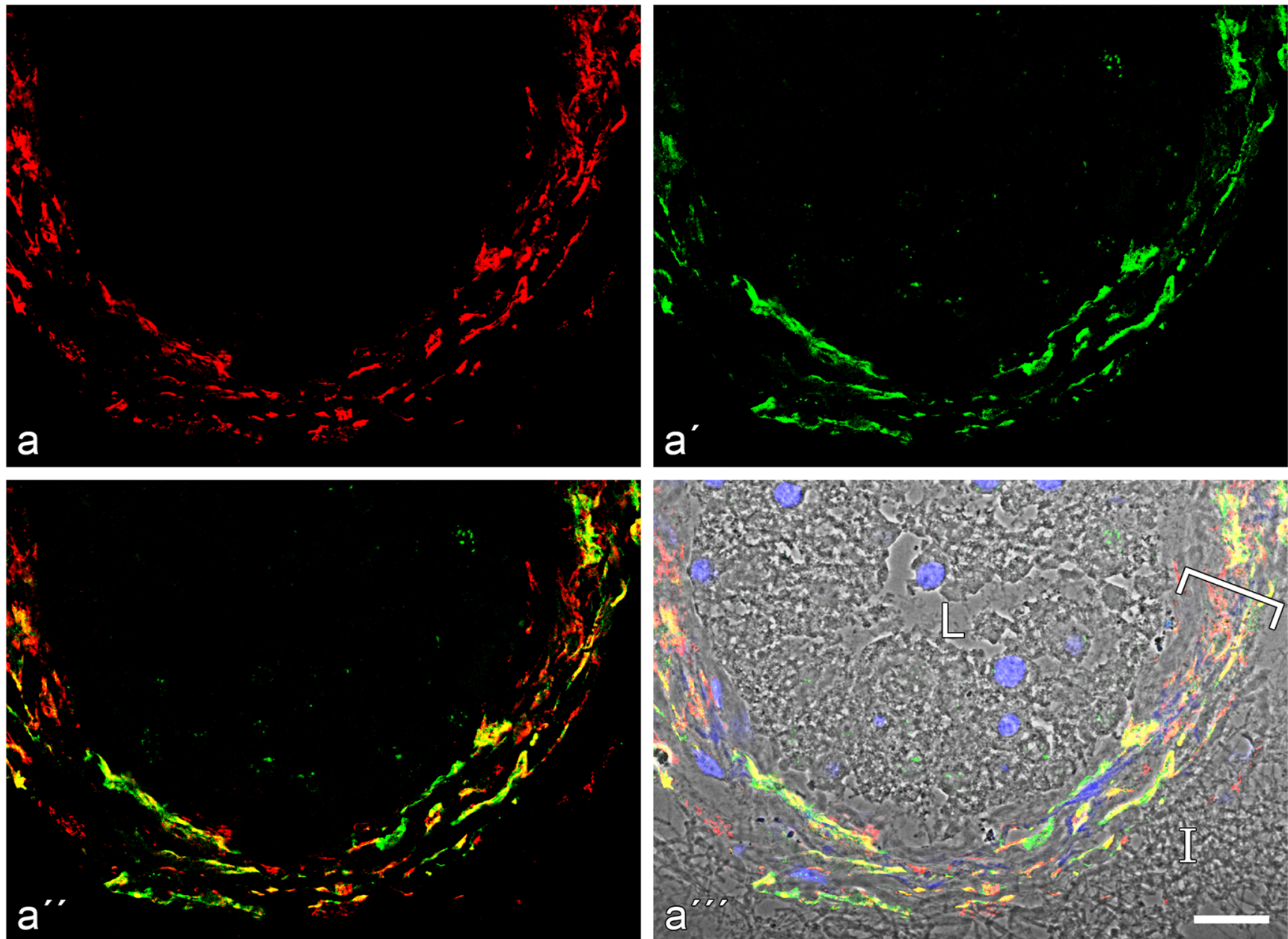

Fig. 5 Double-label immunofluorescence microscopy showing a cross section of a part of the lumen (L) and the peritubular wall (bracket) of a seminiferous tubule in snap-frozen human testis (adult) with far-reaching but not total colocalization (yellow merge color) of smooth muscle myo$\sin (\mathrm{a}, \mathrm{a}$ ", a"'; red monoclonal mouse antibodies) and SMA (a'-a"';

testicular excurrent ducts and other tissues (for some examples, see e.g., ESM, Figs. S9-S11). As an example, one of the larger muscle protein molecules, talin $(270 \mathrm{kDa})$, is shown in comparison with SMA (ESM, Fig. S3a-a"). And finally, dystrophin $(427 \mathrm{kDa})$, apparently the product of the largest mammalian gene which can occur in various isoforms, is seen again in comparison with smoothelin (Fig. 7a) and desmin (Fig. 7b, c). As in diverse kinds of muscle cells dystrophin is mostly associated with distinct regions of the inner surface of the plasma membrane (for dystrophins in SMCs see, e.g., North et al. 1993; Culligan et al. 1998; Vannucchi et al. 2002; Ramírez-Sánchez et al. 2005; Halayko and Stelmack 2005; Ito et al. 2006; Anastasi et al. 2007), it is assumed to characterize special plasma membrane fields and functions.

Finally, the $\mathrm{Ca}^{2+}$-binding and $\mathrm{Ca}^{2+}$-regulator molecules mentioned in Table 1, including the smallest SMC-specific molecule SM22 $\alpha$ and calponin, have been examined (ESM, Figs. S3 and S4; for references, see also ESM, SLC 3b). So far, we cannot decide whether the local differences seen here

green; rabbit antibodies; on a phase contrast background in a"'). Nuclei have been stained blue with DAPI (a"'). Note the broader ECM regions between the LSMCs, probably reflecting some pathological or agingrelated alterations. I interstitial space. Bars $20 \mu \mathrm{m}$

are related to specific calponin isoforms, different scaffolding forms, or differences of epitope accessibility (see, e.g., also the different immunostaining patterns obtained for rat testis reported by Zhu et al. 2004). The LSMCs have also been intensely immunostained by antibodies against caveolin-1 (for specific references see ESM, SLC No. 3c).

Generally, the same SMC-typical molecules have also been recognized in the peritubular walls of the excurrent duct system as well as in the much thicker outer SMC bundles associated with these ducts which are totally different in threedimensional organization than that of LSMCs (for details see ESM, Figs. S9-S11; cf. Baumgarten et al. 1971).

\section{AJs of the monolayer LSMCs and their special lateral end-on-end and vertical alter super alterum arrays in overlapping cell protrusions}

As the LSMCs are tightly connected with each other in the specific monolayer, it has been important to analyze 

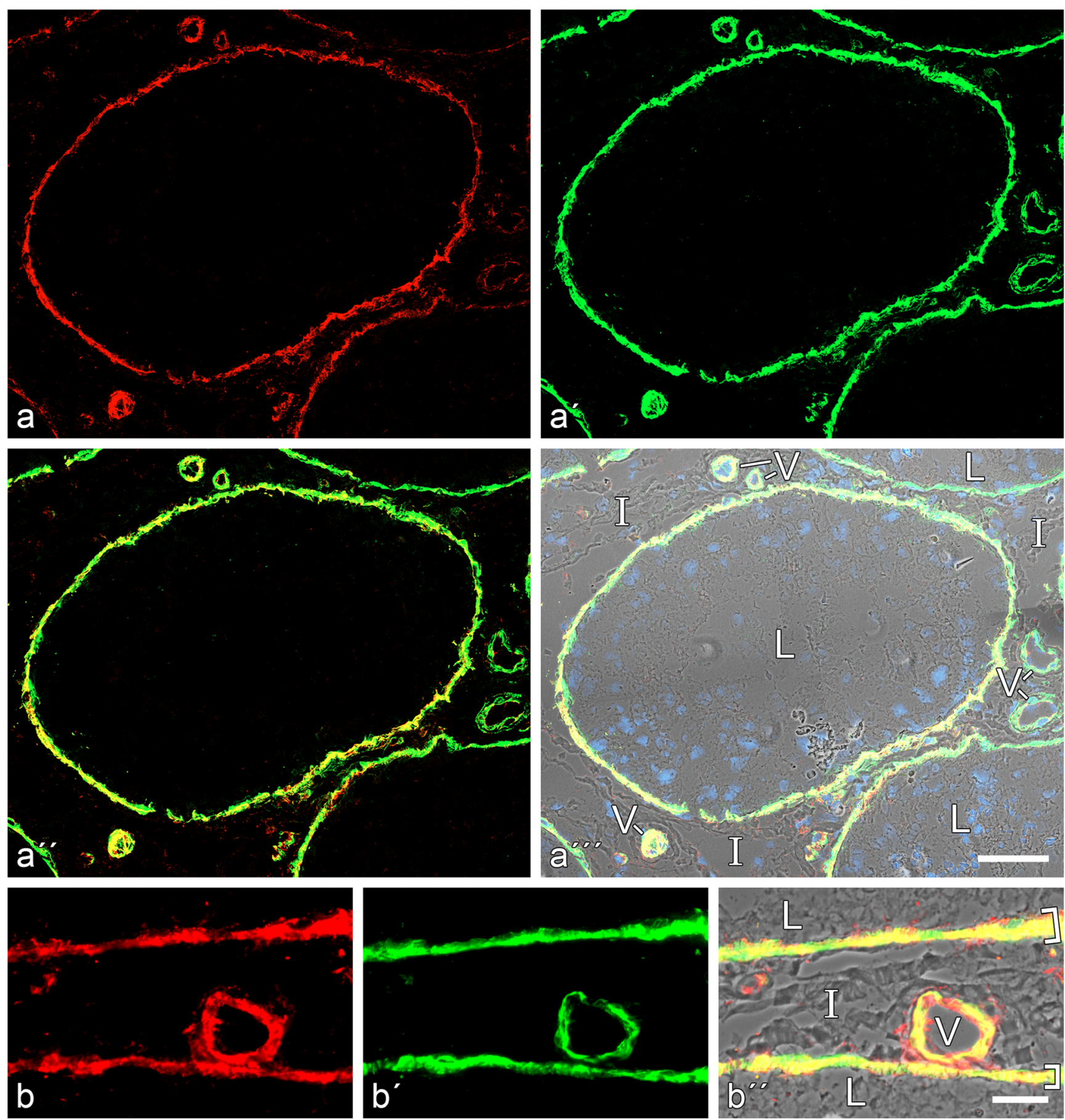

Fig. 6 Double-label immunofluorescence microscopy of cryotomy sections through seminiferous tubules ( $\mathrm{L}$, lumen) of bull testis after reactions with rabbit antibodies against filamin A (a, a", a"', b, b"; red) and monoclonal mouse antibodies to SMA (a'-a"', b', b"; green; phase

contrast background in a"'). Filamin A and protein SMA are localized in the SMCs of the peritubular (brackets in b") and the vascular (V, blood vessels) walls, mostly in colocalization (yellow merge color). I interstitial space. Bars $50 \mu \mathrm{m}$ (a), $20 \mu \mathrm{m}$ (b)

the cell-cell connections, mechanisms, and structures involved and to determine their molecular compositions. In addition to the end-on-end AJ-containing contacts, we have frequently noted regions in which-mostly very flat-lamellipodial protrusions of LSMCs are in rather close and extended overlapping contact with similar lamelliform protrusion structures of adjacent cells (type: processus alter super alterum, ASA). By immunocytochemistry, we have found that these overlapping membranes contain AJs with the by far most frequent transmembrane glycoprotein in this tissue, cadherin-11 (CDH11; OB-cadherin; Okazaki et al. 1994; Hoffmann 

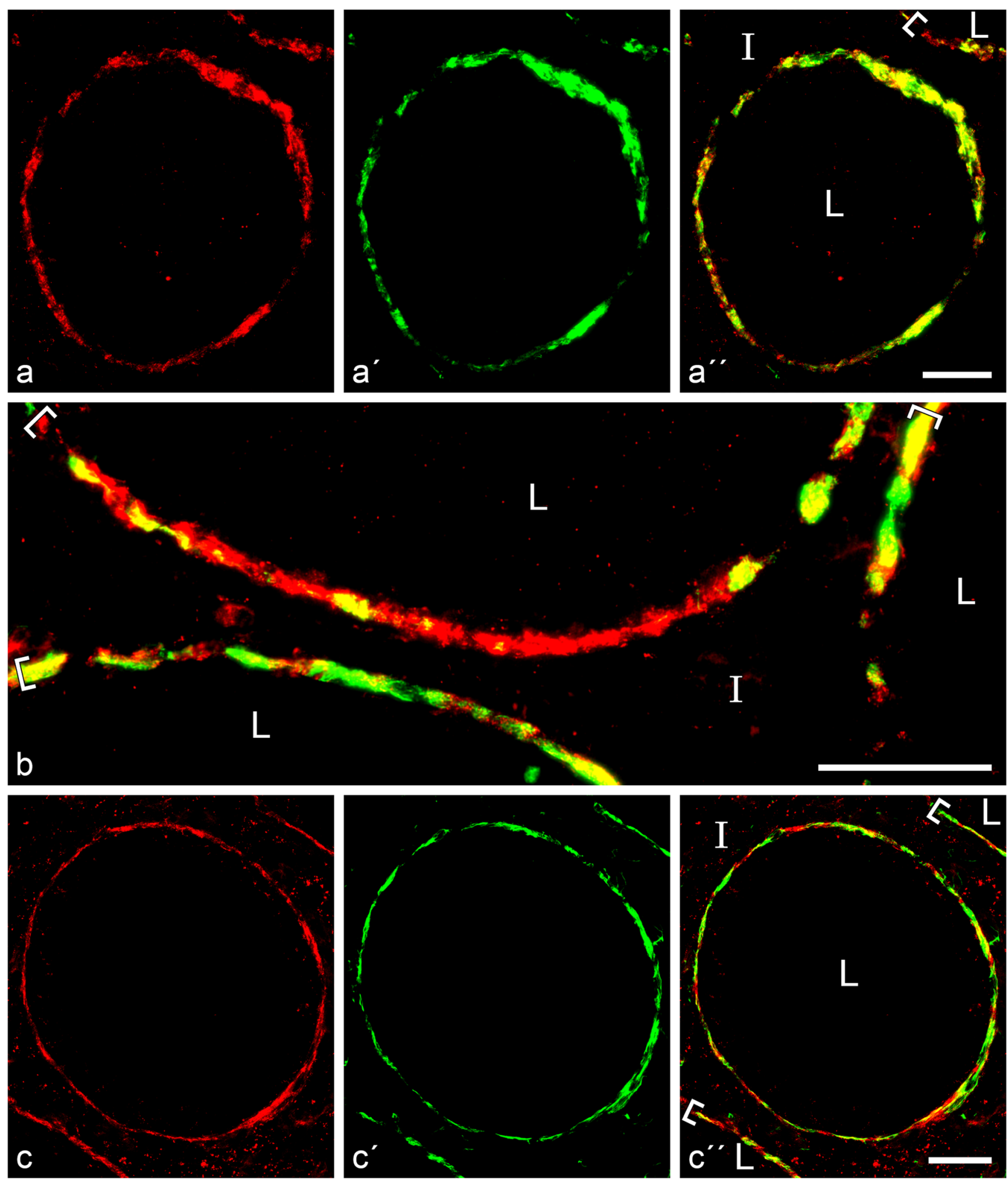

Fig. 7 Double-label immunofluorescence microscopy of a cryotomy cross section through seminiferous tubules ( $\mathrm{L}$, lumen) of $(\mathrm{a}, \mathrm{b})$ bovine and (c) boar testis after reactions with rabbit antibodies against protein dystrophin (a, a", b, c, c"; red) and monoclonal mouse antibodies to

and Balling 1995; Kimura et al. 1995; Simonneau et al. 1995; Alimperti et al. 2014; see also ESM, SLC No. 4), a smoothelin (a', a"; green) and desmin (b, c', c"; green). The peritubular wall cells (brackets) are positive for all three smooth muscle marker proteins showing partly colocalization (yellow merge color). I interstitial space, L lumen. Bars $50 \mu \mathrm{m}$

type II cadherin which is also seen in AJs of cells of the interstitial space (Fig. 8a-e presents bovine and human 

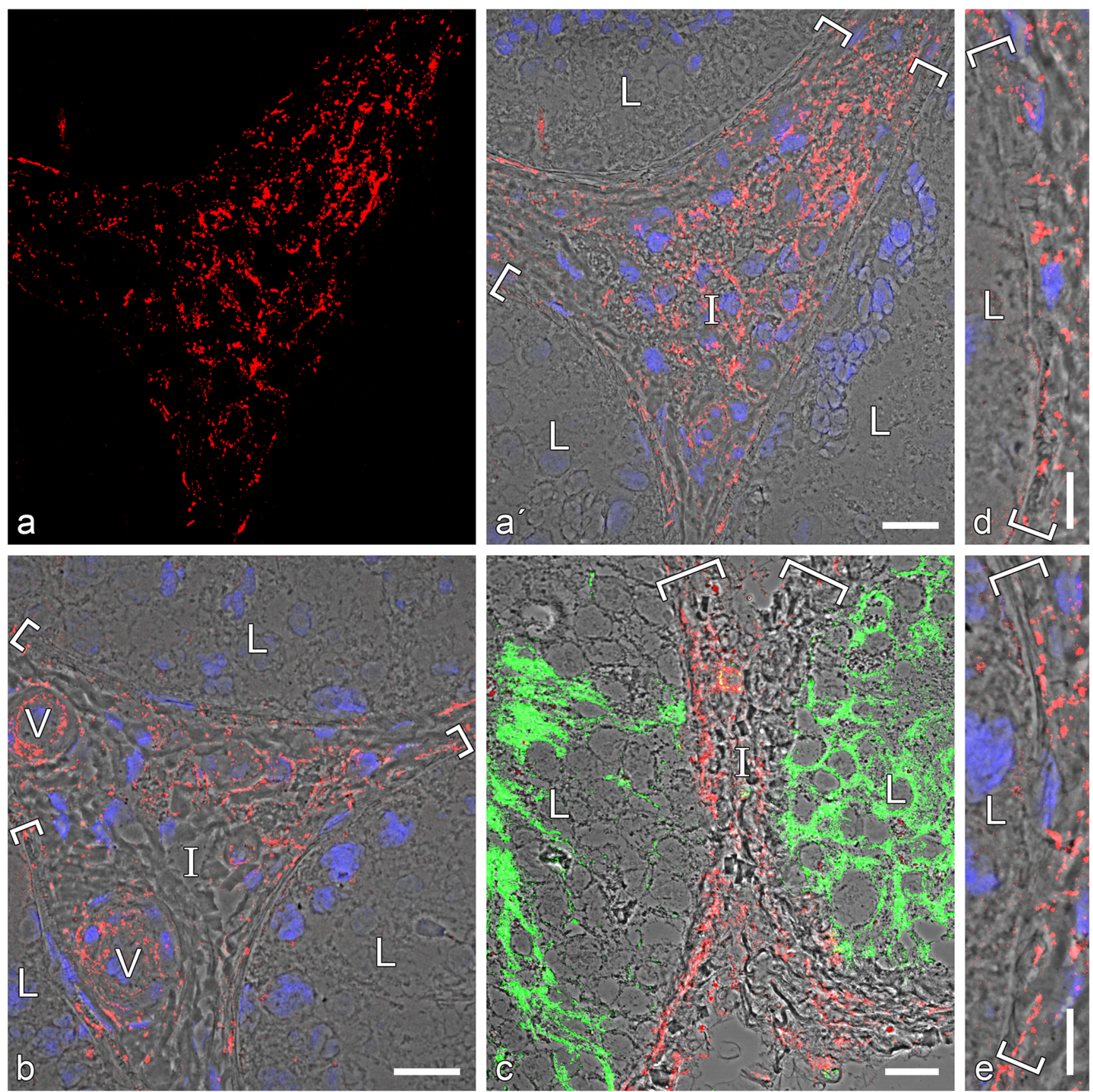

Fig. 8 Double-label immunofluorescence microscopy of cross sections through frozen bovine (a, b, d, e) and human (c) testis after reactions with monoclonal mouse antibodies against cadherin-11 (a, a', b, c, d; red) and rabbit antibodies to $\mathrm{N}$-cadherin (c; green). (a, b, d, e) Positive punctate reactions for cadherin-11 are seen in some places of the peritubular wall

examples). The fundamental molecular difference between the transmembrane AJ structures, within the seminiferous tubules (areae adhaerentes) on the one hand and these junctions in the peritubular wall cells on the other, is directly seen in Fig. 8c in an obliquely grazing section; Ncadherin is the dominant - often apparently exclusivecadherin base of the AJs between Sertoli cells and between Sertoli and germ cells (see also Domke et al. structure (brackets) around the seminiferous tubules (L, lumen; shown at higher magnification in $\mathrm{d}$ and e) as well as in blood vessel (V) walls and in some other interstitial cells (I). (c) Sertoli cells, however, are totally negative for cadherin-11 but positive for $\mathrm{N}$-cadherin. Nuclei have been stained blue with DAPI (a', b, d, e). Bars $20 \mu \mathrm{m}(\mathrm{a}, \mathrm{b}, \mathrm{c}), 10 \mu \mathrm{m}(\mathrm{d}, \mathrm{e})$

2014), whereas cadherin-11 appears to be absent in the tubules but is the predominant basis molecule of the AJlike junctions of the LSMC structures.

Another relatively frequent cadherin identified in LSMCs of adult testes is, rather surprisingly, P-cadherin (CDH3), which is known as a major component of AJs of certain epithelia, for example, the basal cell layers of several stratified epithelia (see e.g., the example of bovine 

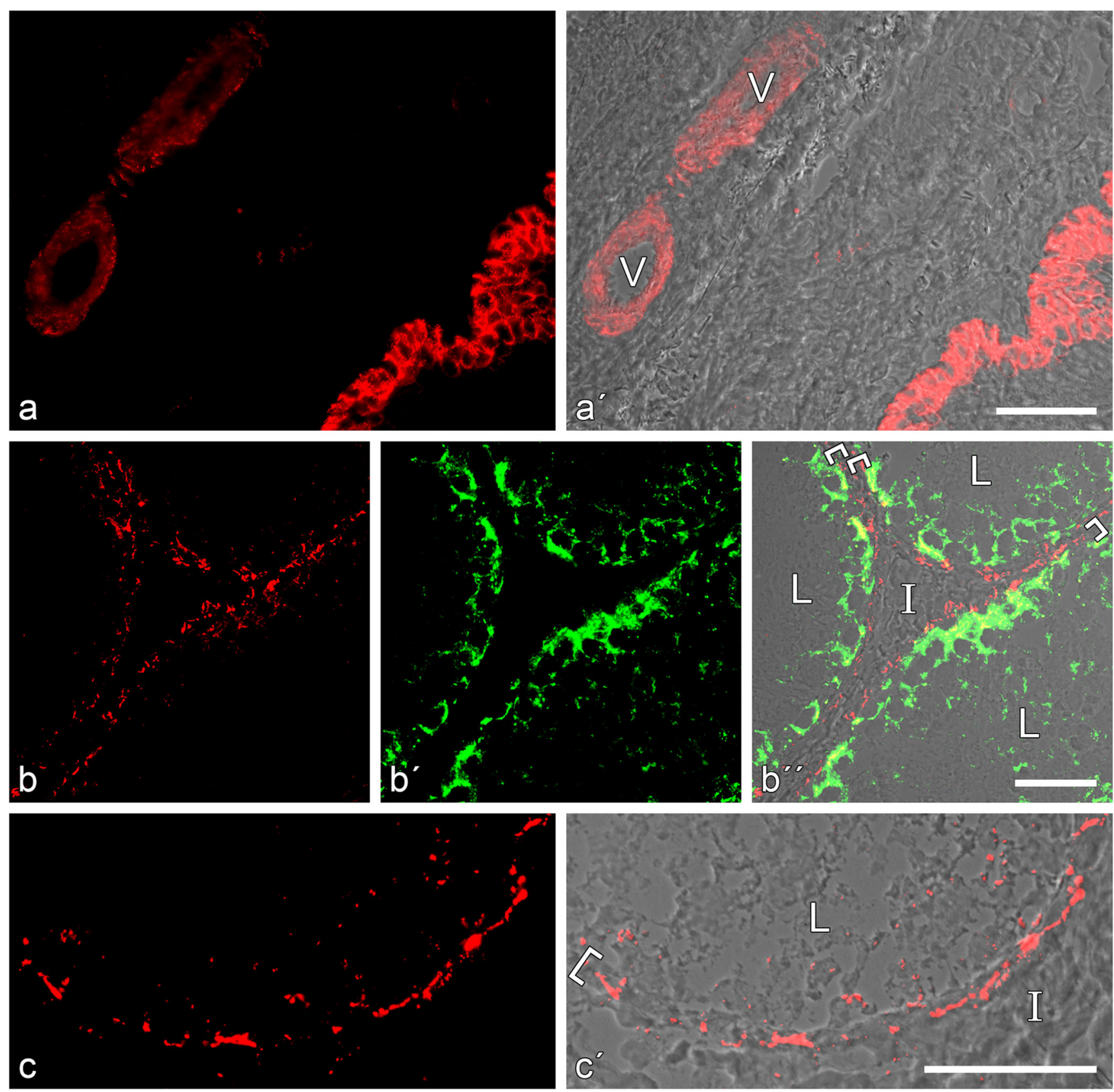

Fig. 9 Double-label immunofluorescence microscopy of cryotomy cross sections through frozen (a) bull tongue mucosa and (b, c) bull seminiferous tubules after reactions with rat antibodies against $\mathrm{P}$-cadherin $(\mathrm{a}, \mathrm{a}, \mathrm{b}$, b", c, c'; red) and N-cadherin (b'-b"; green; monoclonal mouse antibody). (a) Positive reaction for P-cadherin is seen in SMCs of blood vessel (V) as well as in the basal layer(s) of tongue mucosa. Peritubular

wall cells (brackets in b", c, c') surrounding the seminiferous tubules (L, lumen) also show positive immunoreaction for P-cadherin. Here, Sertoli cells are negative for $\mathrm{P}$-cadherin but positive for $\mathrm{N}$-cadherin (the cell biological significance of the punctate reaction sites in yellow merge color is not yet clear). I interstitial space. Bars $50 \mu \mathrm{m}$

tongue mucosa in Fig. 9a, a'; for general references, see e.g., Nose and Takeichi 1986; Johnson et al. 1993; Wu et al. 1993; Furukawa et al. 1997). One of its rare occurrences in non-epithelial tissues is that noted in the peritubular wall LSMCs which has already been mentioned-specifically for post-puberty rats-by Lin and DePhilip (1996a, b). Whether in addition to the peritubular wall LSMCs and some cell groups in the

interstitial space, certain sparse punctate $\mathrm{CDH} 3$ molecular reactions are associated with certain Sertoli cells (see e.g., Fig. 9b", c, c') cannot yet be decided (for rat fetal and postnatal testes, see e.g., Lin and DePhilip 1996a, b.

In LSMCs of peritubular walls of some mammalian species, punctate or plaque-like structures containing Ecadherin have been detected in addition to cadherin-11 (e.g., ESM, Fig. S5 b, c; for bovine peritubular walls, see 

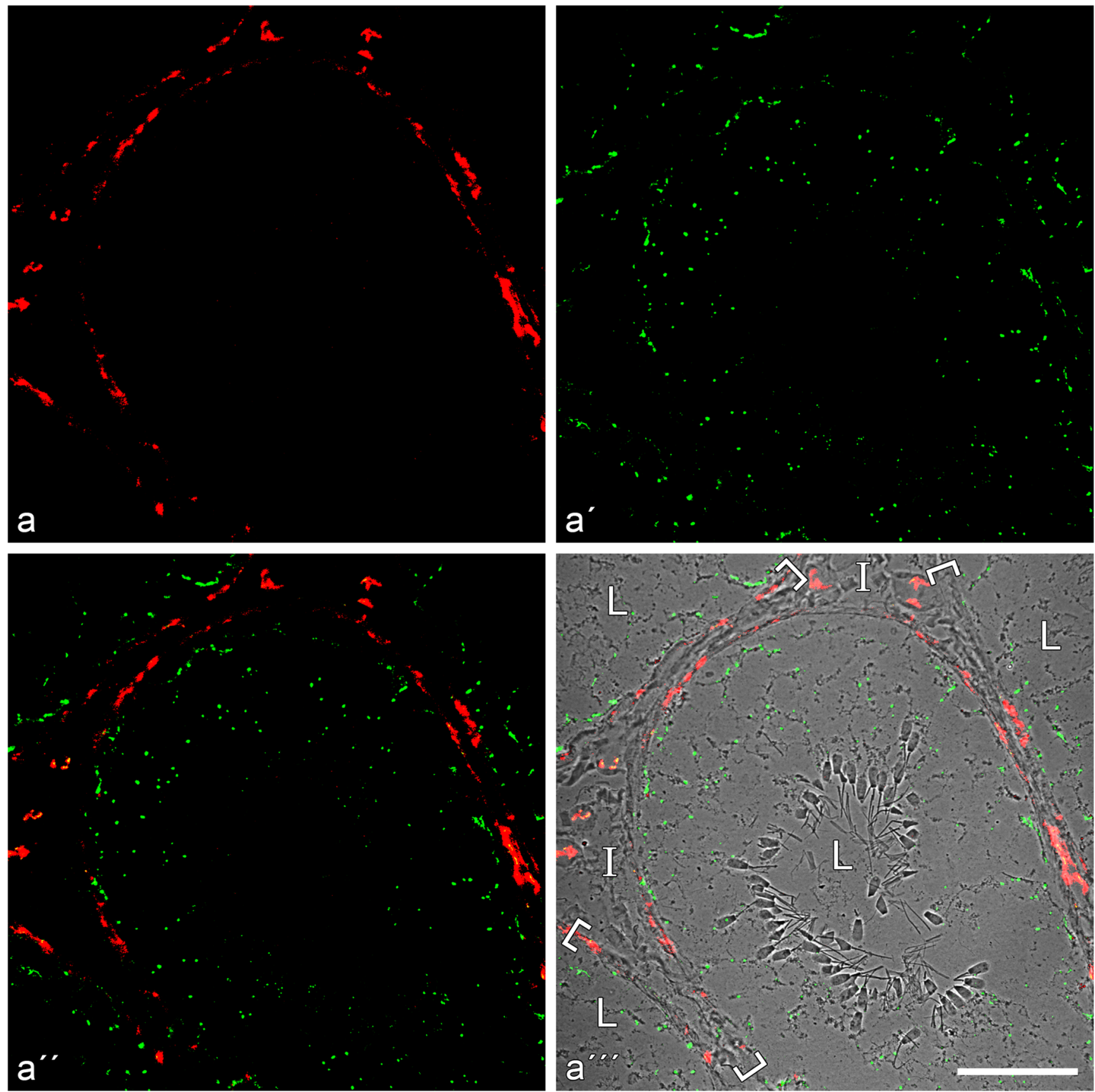

Fig. 10 Double-label immunofluorescence microscopy of a cryotomy green). The peritubular wall cells are positive for myozap and partly also for $\beta$-catenin. All Sertoli cells are positive for $\beta$-catenin but negative for myozap. Note totally negative spermatids in the lumen. I interstitial space. Bar $50 \mu \mathrm{m}$

after reactions with monoclonal mouse antibodies against protein myozap (a, a", a"'; red) and rabbit antibodies to $\beta$-catenin (a'-a"';

also Fig. 4 of Domke et al. 2014). These findings, so far obtained with only one of the antibodies used, are remarkable as this cadherin is known to occur regularly and primarily only in epithelial and epithelium-derived cells (for references, see e.g., Vestweber and Kemler 1984; Takeichi 1990; Perez and Nelson 2004; Meng and Takeichi 2009)

but appears to be totally absent in AJs and other structures of mature Sertoli and germ cells (see e.g., Cyr et al. 1992, 1993; Newton et al. 1993; Byers et al. 1994; Domke et al. 2014).

In addition to $\beta$-catenin, the ensembles of the cytoplasmic plaque proteins present in LSMCs include plakoglobin, 
striatin family proteins, and protein p0071. In addition, a striking new finding in LSMCs has been the identification of the $54-\mathrm{kDa}$ protein myozap as a major AJ component in bovine testes (Figs. 10 and 11) as well as in testicular regions of some other species. This cytoskeletal protein, discovered by Seeger et al. (2010) as a major plaque component of the cardiomyocyte composite junctions (areae compositae), has since also been shown to be a constitutive element of the zonula adhaerens AJs of E-cadherin-based epithelia (Rickelt et al. 2011) as well as a general component of endothelial AJs of mammalian blood and lymph vessels (Pieperhoff et al. 2012). As shown in Figs. 10 and 11, protein myozap, which has not been detected in the AJ types of Sertoli cells (cf. Domke et al. 2014), except for rodent testes, also occurs in the AJs of the endothelia of testicular blood vessels (note in particular in Fig. $11 \mathrm{a}-\mathrm{d}$, the extensive myozap and $\beta$-catenin co-immunostaining indicative of colocalization).

Protein LUMA, which has also been reported to occur in the composite junctions of cardiomyocytes (e.g., Franke et al. 2014), can as well be detected in LSMCs of peritubular walls and in the SMCs of certain blood vessel walls, but not in Sertoli cells (Fig. 12). Moreover, protein LUMA has also consistently been found in association with the heterotypic cell-cell junctions connecting the nucleus-containing ("head") part of the spermatids (for topologically corresponding molecular markers, see Franke et al. 1978a; Longo et al. 1987; Hess et al. 1993, 1995; von Bülow et al. 1995; Heid et al. 2002) with the specific nectinpositive indentations of the apical plasma membrane of Sertoli cells (see e.g., Ozaki-Kuroda et al. 2002; Takai and Nakanishi 2003; Guttman et al. 2004; Inagaki et al. 2006).

\section{Compositional heterogeneities of IF proteins in LSMCs of peritubular walls}

Positive immunofluorescence reactions of LSMCs are often seen for both IF proteins, desmin, and vimentin and have been reported for SMCs of various kinds, in some cells also as heteropolymer IFs (e.g., Gard and Lazarides 1980; Berner et al. 1981; Frank and Warren 1981; Gabbiani et al. 1981, 1982; Schmid et al. 1982; Quinlan and Franke 1982, 1983; Franke and Quinlan 1983; van Vorstenbosch et al. 1984; Soellner et al. 1985, Virtanen et al. 1986; van Muijen et al. 1987). However, the intracellular distribution of these two IF proteins can differ markedly and does not indicate an obligatory colocalization in the same filament (for review, see Quinlan et al. 1985). To the contrary, these immunostaining reactions can show, besides colocalization regions, specific localization differences between species, in different LSMC layers of the same peritubular wall, or even between different regions in the same LSMC.
Initially surprising, but generally in agreement with reports of molecular analyses of other SMC tissues, is our finding that in bull and boar testes several LSMC layers also contain the IF proteins CK8 and CK18 (Fig. 13a-e; ESM, Figs. S5-S7). This adds the LSMCs of the testicular peritubular wall of certain mammalian species to the list of SMC subtypes which in general contain type I and type II CKs and apparently can form typical CK IF structures in addition to IFs of desmin or vimentin or both (ESM, Table S2). Detailed immunofluorescence microscopic analysis has further revealed that in some places, desmin and CK IFs are in close contact, as indicated by the merge color (e.g., ESM, Figs. S5 and S6), whereas in other regions, separate localizations of desmin and vimentin on the one hand and CKs on the other are prevalent (see, e.g., Fig. 13b-e as well as ESM, Figs. S5-S7).

\section{Cell architecture, ultrastructural, and molecular components of the cells of the peritubular wall: electron and immunoelectron microscopy}

The characteristic, bandage-like peritubular wall organization of alternating ECM layers and LSMC monolayers is shown in cross sections in Figs. 14, 15, 16, and 17. The Sertoli cells are attached to the basal lamina which is followed by a first ECM layer with close-packed bundles of collagen fibrils which for the most are oriented in parallel to the seminiferous tubule, followed by another LSMC monolayer, another collagen fibril-dominated ECM layer, and even another LSMC monolayer. While in the rodent species, we have usually noted only one LSMC layer, often covered by an extremely thin lamellar fibrocytoid cell layer (see below); in other species, we have recognized three, four, even five, or six ECM-LSMC pairs (see e.g., Figs. 14, 15, 16, and 17; for a special review, see Christl 1990). The thicknesses of the collagen fibril-rich ECM layers and the LSMC monolayers can vary markedly, also locally in the same layer. In relatively large portions of bull testis LSMCs, for example, the cytoplasmic thickness of the very thin "lamellar flaps" of LSMCs is less than $100 \mathrm{~nm}$, in some extended regions even down to the range of ca. 30$100 \mathrm{~nm}$ (e.g., Figs. 14c, d and 16f), but may exceed $1 \mu \mathrm{m}$ in other - more central - regions, in particular those in which the nucleus is located.

In the LSMC monolayers, variously sized, overlapping lamelliform, or filopodial cell protrusions of the ASA type provide the basis for the formation of close connections between adjacent cells of the same monolayer often with clusters of plaque-attached AJs (e.g., Figs. 14c, d, 15b, d, 16, and 17). In some of these overlapping AJ-rich regions, we could count up to eight plaque-anchored AJ junctions 

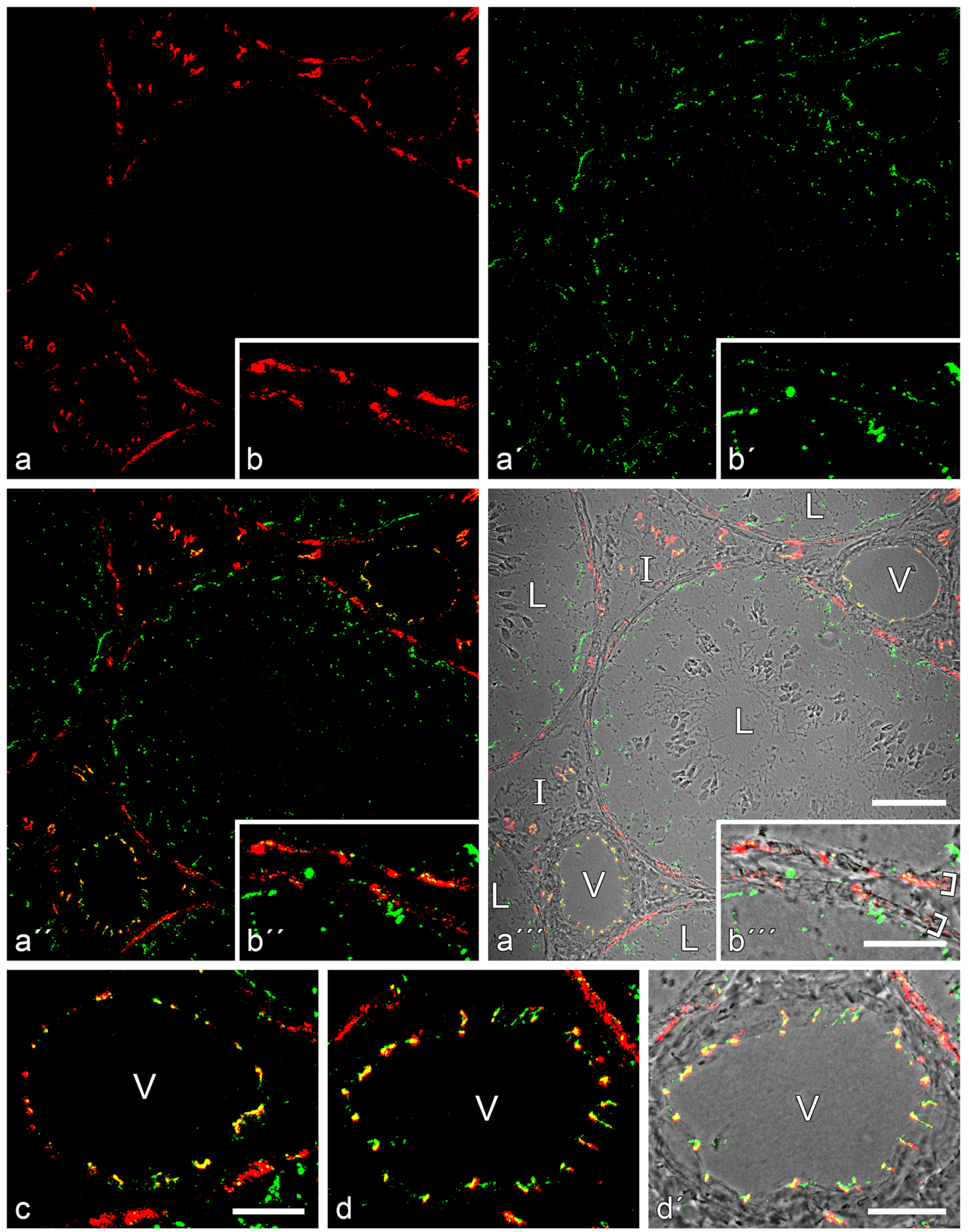
Fig. 11 Double-label immunofluorescence microscopy of cryotomy cross sections through seminiferous tubules (L, lumen) of bull testis after reactions with monoclonal mouse antibodies against protein myozap (a, a", a"', b, b", b"', c, d, d'; red) and rabbit antibodies to $\beta$ catenin (a'-a"', b'-b"', c, d, d'; green). The peritubular and vascular SMC wall cells are positive for myozap and partly colocalize with $\beta$-catenin (punctate sites with yellow merge color, shown at higher magnification in the insert b"-b"'). In contrast, colocalization is very prominent in the adherens junctions connecting endothelial cells of blood vessels ( $\mathrm{V}$, yellow merge color; shown at higher magnification in c-d'). Sertoli cells are positive for $\beta$-catenin but negative for myozap. Note spermatids in the lumen (a"'). I interstitial space. Bars $50 \mu \mathrm{m}$ (a), $20 \mu \mathrm{m}$ (b, c, d)

per ultrathin section in tomographic reconstructions so far up to 15 per lamelliform overlapping ASA structure. The wide variety of sizes and forms, e.g., straight or with curvatures, two or even three protrusions, is shown in Fig. $17 \mathrm{e}-\mathrm{f}$.

In the thicker portions, the LSMCs often contain typical "dense bodies," some of which may exceed $0.5 \mu \mathrm{m}$ in centripetal direction and $1 \mu \mathrm{m}$ in length (e.g., Fig. 15a). The packing density of myofilaments is also rather variable, even in neighboring fibril bundles, including relatively thick bundles with paracrystalline actin and myosin filament arrays, which often occupy the entire cytoplasmic space of that region (e.g., Fig. 15b, c). As seen with special clarity in cross sections through seminiferous tubules and their peritubular walls, the orientations of the myofilament bundles can vary between specific LSMC layers, even in neighboring ones: In some LSMC layers, they are oriented coaxially with the seminiferous tubule (see e.g., layer nos. 1 and 2 in Fig. 15a); in others, they appear in an almost circular or somewhat oblique orientation with respect to the axis of the specific seminiferous tubule (see e.g., Figs. 14c, d, and 15a). Frequencies and cluster arrays of plaque-bearing focal adhesions (for reviews, see Jockusch et al. 1995; Critchley 2004; Dubash et al. 2009) and of plasma membrane caveolae (e.g., Figs. 14d-f and $15 \mathrm{a}-\mathrm{b})$ also show marked local variations.

The locally sometimes very high packing densities of myofilaments as well as the local frequencies of dense bodies, focal adhesions, and caveolae are in the range typical of other kinds of SMCs (for caveolae and caveolin-1, see e.g., ESM, SLC No. 3c). Particularly striking in cross sections is generally the high frequency of myofilament arrays with an identical orientation, often even in dense, paracrystalline packing (e.g., Fig. 15c). Our observations of coaxially oriented myofilament bundles in a given LSMC are obviously in contrast to claims of some other authors that - at least in rodents - in the same LSMC region myofilament bundles may exist that are oriented in different directions (see e.g., Losinno et al. 2012, 2016).
Some AJ-like structures connecting LSMCs appear-at relatively low frequency - as rather short end-on-end junctions. As aforementioned, however, most of the AJs are located in closely overlapping, often very broad lamelliform ASA protrusions (e.g., Figs. 16a, c-f and 17). Occasionally, LSMC invaginations (recessus adhaerens; cf. Wuchter et al. 2007) into an adjacent LSMC are seen which are also studded with AJs (e.g., indicated by the arrow in the right hand part of Fig. 16a). In addition, cell-cell contacts with a very small intercellular distance (ca. 5-10 nm) but hardly—or not at all - detectable intercellular structures are also often recognized (e.g., Figs. 16d-f and 17).

Using immunoelectron microscopy on frozen tissue sections, we have localized in all LSMC layers typical AJ plaque components, including $\beta$-catenin and protein myozap (Fig. 18a-e), while cadherin-11 appears as the major transmembrane glycoprotein with predominant heavy metal label enrichment in intermembrane regions (Fig. 18f-h).

\section{Discussion}

\section{Major results and conclusions}

Our analyses of the cell and molecular biological components and structures of the peritubular wall cells have resulted in the identification and definition of a new cell type and a new tissue as well as a new cell-cell junction system.

(a) With respect to their molecular and ultrastructural components, the peritubular wall cells are complete and welldifferentiated smooth muscle monolayer cells of a unique morphology, characterized by an omnidirectionally extended and flattened, polygonal cell shape and-for the most part - densely packed structures, including myofilament bundles of various diameters, in some places even in paracrystalline packing. Therefore, we subsume these cells under the special category of "lamellar smooth muscle cells" (LSMCs).

(b) These LSMCs are not polar with an apical and a basolateral side, but both sides are covered and separated by ECM structures which often vary in thickness. Thus, one to six LSMC monolayers (the numbers vary in the different species) form alternating LSMC-ECM bandages which are tightly wrapped around the specific seminiferous tubule.

(c) In a given monolayer, the LSMCs are tightly connected with adjacent LSMCs in end-on-end cell-cell junctions, but major parts of their plasma membranes form closely parallel, overlapping lamelliform, or oblique cell 

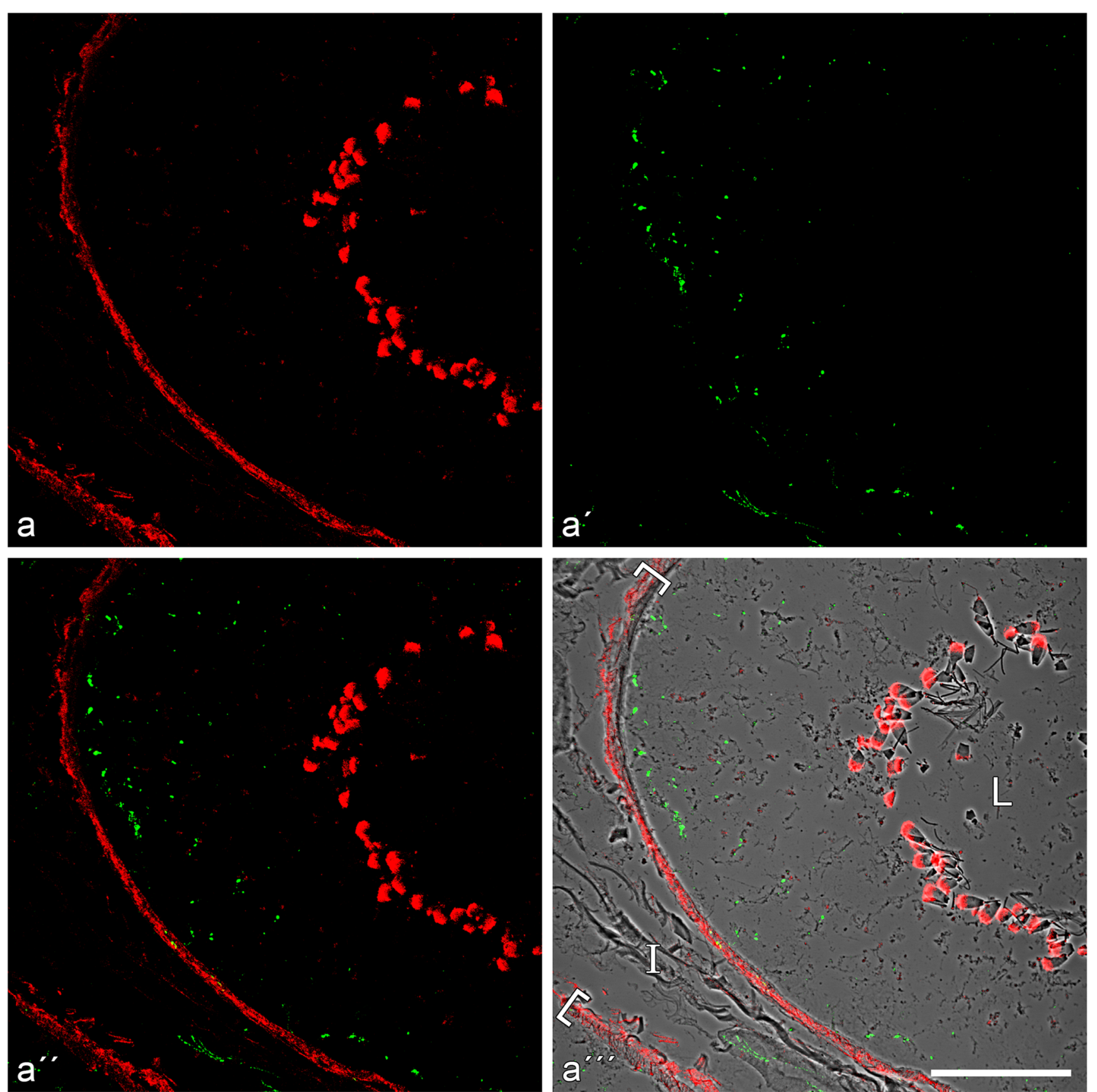

Fig. 12 Double-label immunofluorescence microscopy showing a cross section through a part of the lumen (L), the seminiferous epithelium, and the peritubular wall (brackets) of a seminiferous tubule in snap-frozen bull testis after reactions with antibodies to protein LUMA (a, a", a"';

protrusions of the ASA type in which these cells are vertically and stably connected by a variable number of AJs, i.e., a totally novel architectonic mode to form and enhance lateral connections ("lateral by vertical").

red; guinea pig antibodies) and $\beta$-catenin ( $\mathrm{a}$ '-a"'; green; monoclonal mouse antibodies; on a phase contrast background in a"'). Protein LUMA is localized in LSMCs of the peritubular walls and in spermatid heads in the lumen. I interstitial space. Bar $50 \mu \mathrm{m}$

(d) The AJs of these LSMCs which - apparently for the most part - are based on cadherin-11 represent a compositionally new molecular subtype of SMCs, in some species surprisingly characterized by the major plaque protein myozap. 

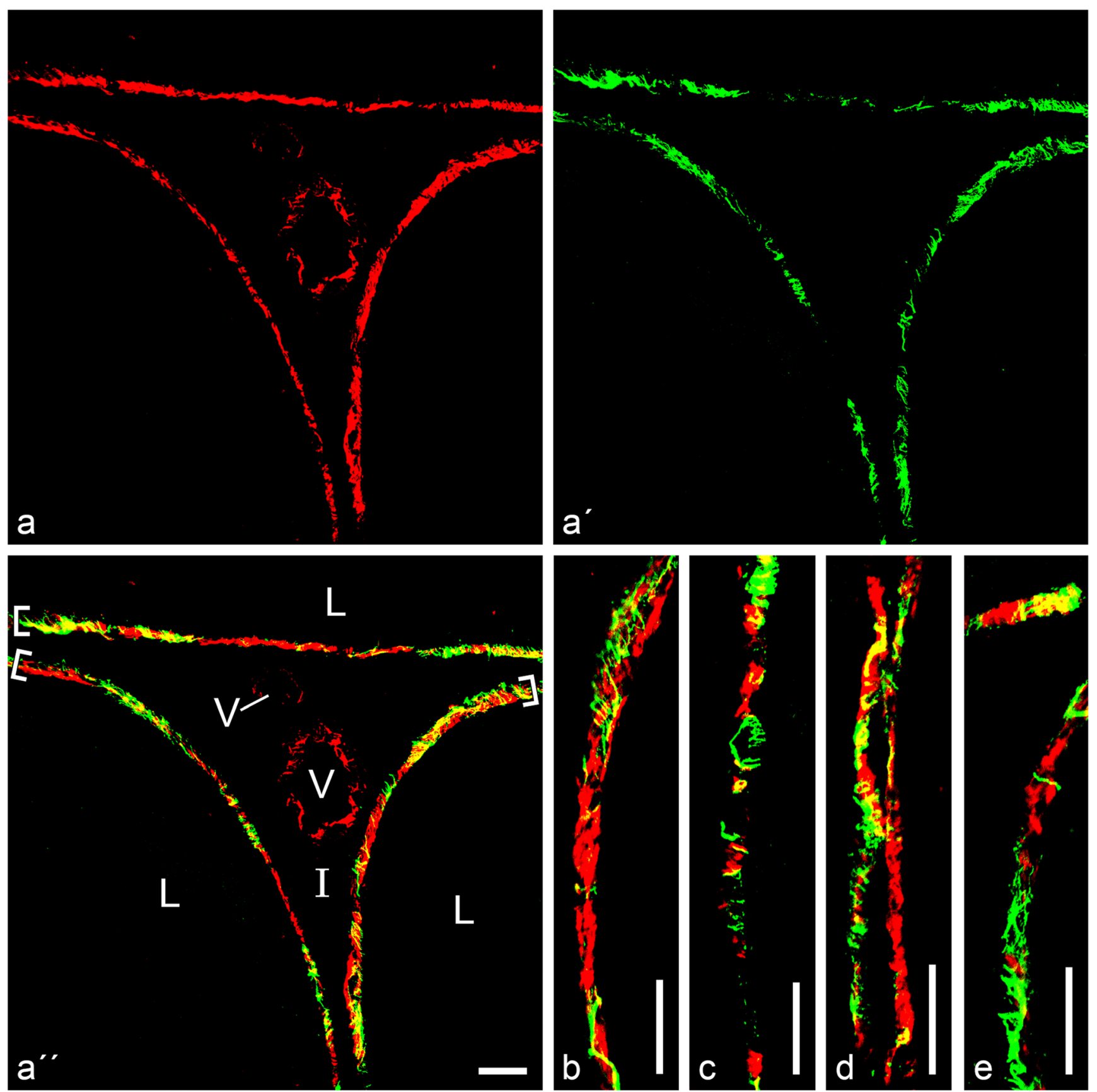

Fig. 13 Double-label immunofluorescence microscopy of cryotomy sections through bull testis, showing that SMCs of the peritubular wall of the seminiferous tubules (L, lumen; walls denoted by brackets in a") contain regions positive for smooth muscle $\alpha$-actin (SMA; a, a", b-e; red; monoclonal mouse antibodies) and others positive for the intermediatesized filament proteins cytokeratins (CKs) 8 and 18 (a'-e; green; guinea

pig antibodies) as well as some small overlapping regions (yellow merge color). Note also the exclusive SMA positivity in certain perivascular walls (V, vessels). At higher magnification (b-e), various fibrillar patterns of CK positivity are recognized, including regions with oblique and crossstriation structures. I interstitial space. Bars $20 \mu \mathrm{m}$

\section{The peritubular wall-a closed and contractile tissue system encasing the seminiferous tubules}

Since the early cinematographic and microscopic observations of Roosen-Runge (1951) and Clermont (1958), the cells of the peritubular wall have been known as major elements of the internal, i.e., directly seminiferous tubule-associated contractile system in mature mammalian testes (see also e.g., Leeson and Leeson 1963; Hargrove et al. 1977; Leeson and Forman 1981; see 


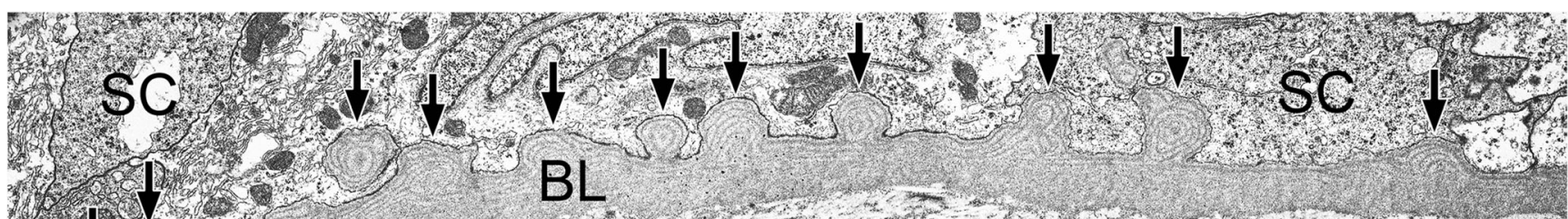
(D)

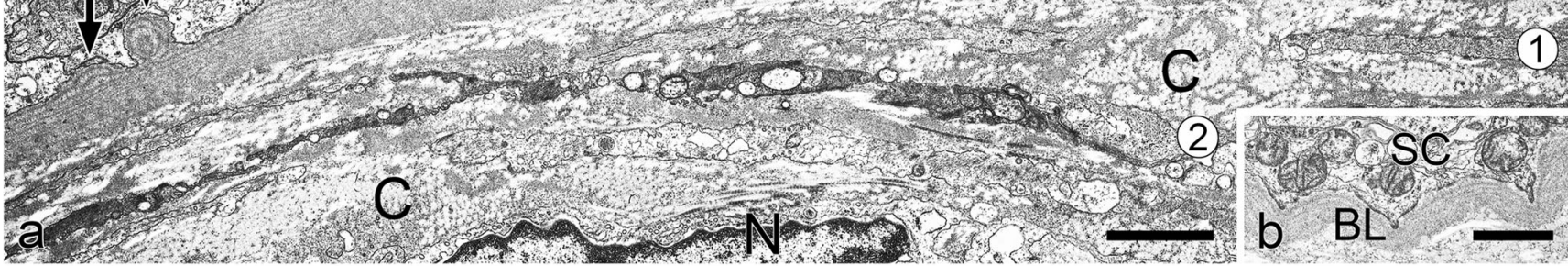

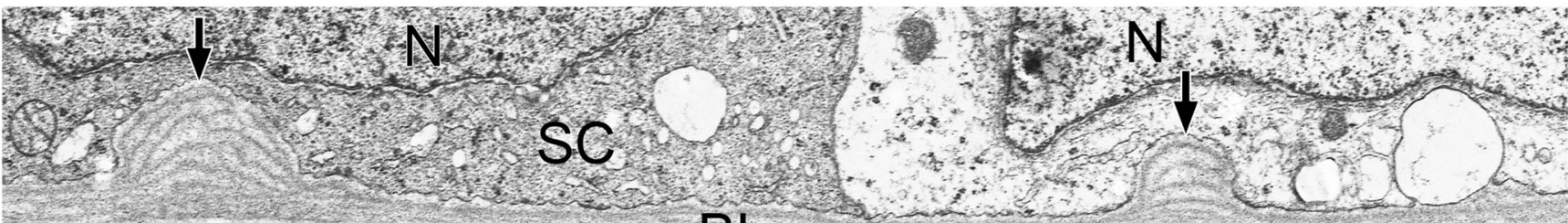

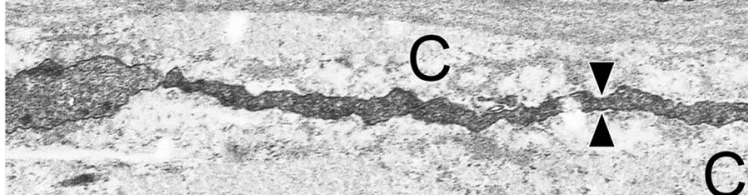

BL

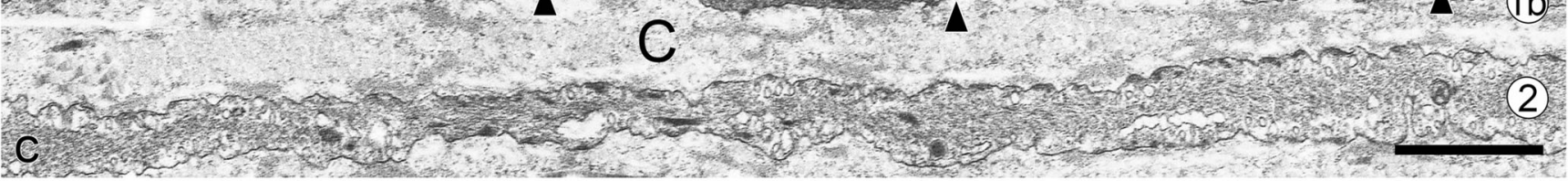

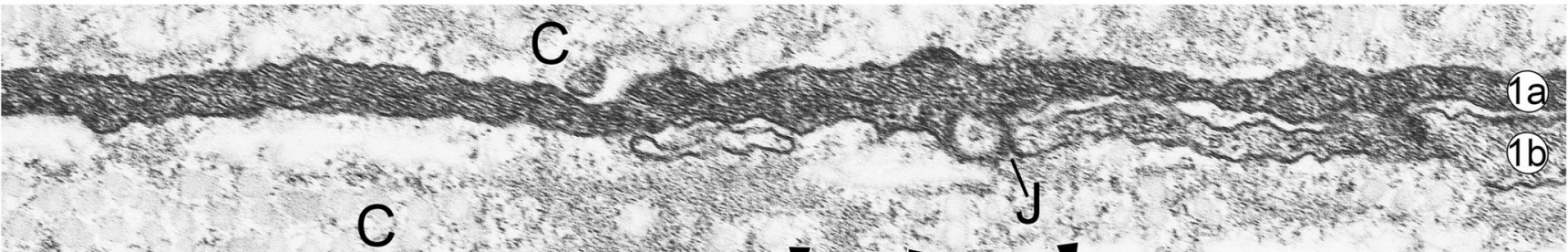

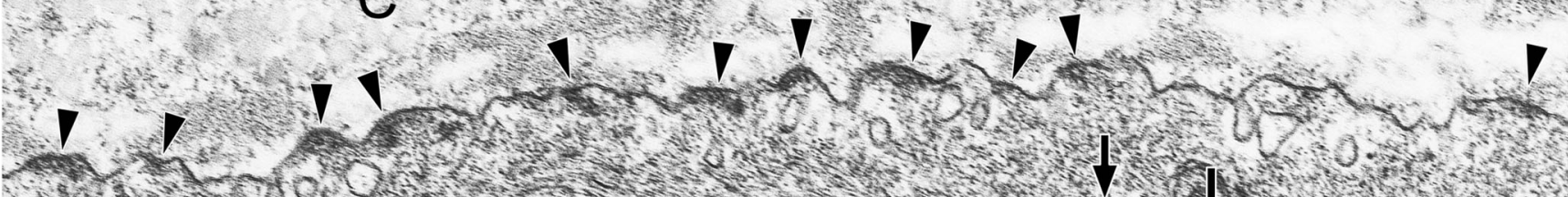

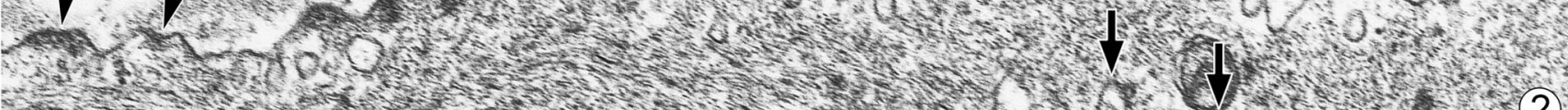

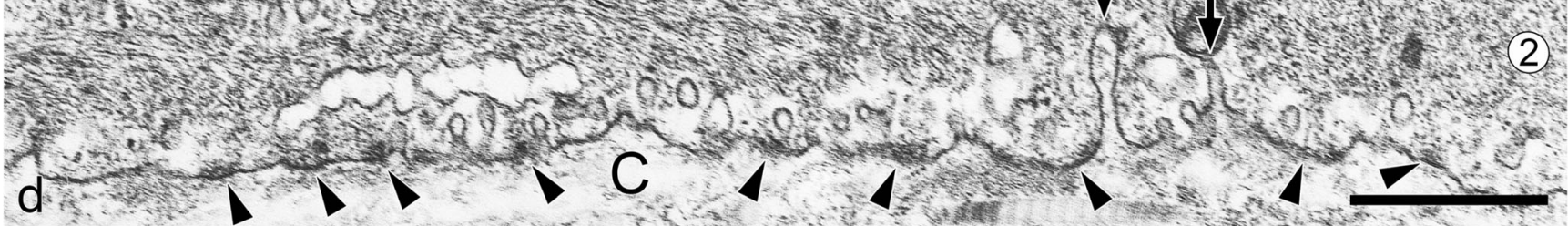

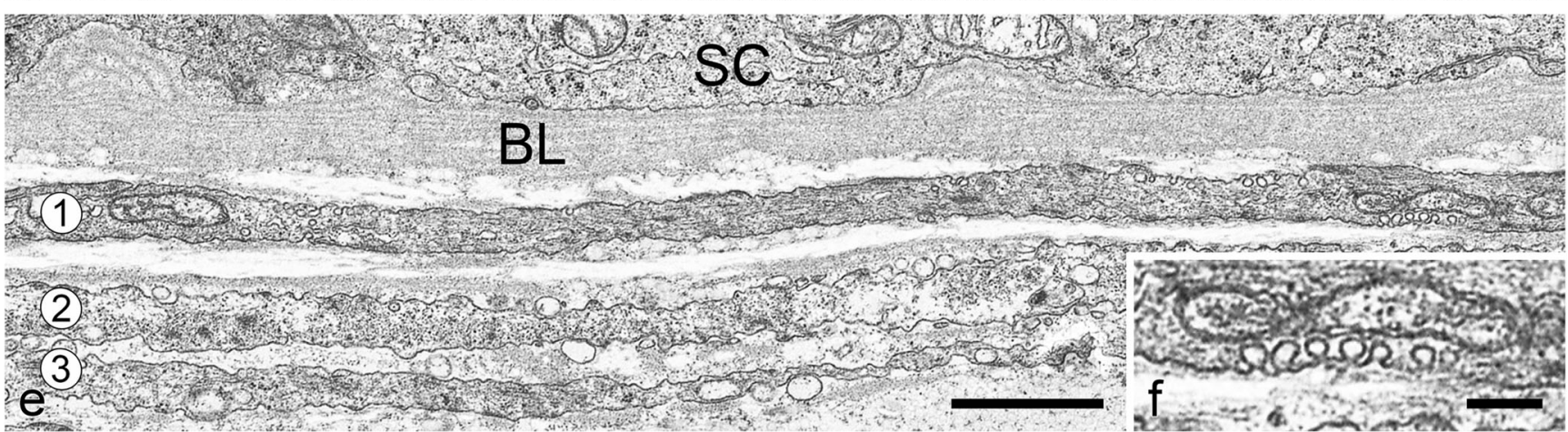


Fig. 14 Electron micrographs of ultrathin cross sections through peritubular wall structures encasing seminiferous tubules of bull testis. a In many regions, the basal lamina (BL) presents rather closely spaced indentations of up to $1.5 \mu \mathrm{m}$ (arrows) into the cytoplasm of the Sertoli cells (SC). In other regions, the basal lamina is for the most part nearly even-surfaced and borders on a collagen (C) fiber-rich extracellular matrix (ECM) layer, followed by the first lamellar smooth muscle cell (LSMC) layer (numbered on the right hand margin: no. 1), another ECM layer, and the second LSMC layer (no. 2). b In some other regions, the SCs show small and short acute protrusions into the BL. c Fili- or lamelliform processes of LSMCs (numbered on the right hand margin) of a peritubular wall surrounding SCs (N nuclei; arrowheads denote BL indentations of the type described in a) are associated with layers of collagen $(\mathrm{C})$ fiber-rich ECM. These special LSMC cytoplasms are very thin (in some places down to a range of 30-100 nm; denoted by arrowheads) and characterized by densely packed actin and actomyosin filaments. d Higher magnification of a part of the region adjacent to that shown in $\mathbf{c}$, demonstrating that here filament bundles are packed much closer in the upper LSMC layer (no. 1) than in the LSMC layer no. 2 ( $\mathrm{J}$ in layer no. 1 denotes a cell-cell junction in an overlapping region). The arrowheads denote the numerous focal adhesions of LSMC layer no. 2, and the two arrows point to relatively narrow plasma membrane invaginations. Note also the numerous caveolae and vesicles at the plasma membrane of the lower LSMC (no. 2). e Subjacent to the SCs and the $\mathrm{BL}$, there are three thin LSMC layers (nos. 1-3) with different myofilament packing densities, many cytoplasmic vesicles, and caveolae. f Higher magnification of a typical caveolae-rich plasma membrane region (seen at the right end of the image of cell layer no. 1 in e). Bars $2 \mu \mathrm{m}(\mathbf{a})$, $1 \mu \mathrm{m}(\mathbf{b}, \mathbf{c}, \mathbf{e}), 500 \mathrm{~nm}(\mathbf{d}), 200 \mathrm{~nm}(\mathbf{f})$

also ESM, SLC No. 1). The contractile function of these cells and its regulation is obviously important for male fertility and has been extensively studied, in particular with respect to the release of the spermatids from their heterotypic attachment structures in the apical indentations of the Sertoli cells and their further translocation into the excurrent duct system, where the mature spermatozoa finally show autonomous motility. Obviously, a central tissue structure functionally involved in these contractions and translocations is the very thin peritubular wall. The second major contractile system of the testis, the outer, i.e., subcapsular SMC system, is very different, in particular more complex and compositionally heterogeneous. We have therefore decided to dedicate a following special report to the cell and molecular biology of the contractile SMC system of the tunica albuginea system.

\section{The LSMCs of the peritubular walls-a special kind of smooth muscle tissue}

The results of our biochemical, immunocytochemical, and electron microscopical studies have shown, apparently in contrast to Galdieri and Ricci (1998), that in the peritubular walls, only one kind of cells exists and that these cells are typical SMCs, even though they often vary in shape, thickness, lamelli- and fusiform processes, and distribution patterns of cytoplasmic structures. This general classification as LSMCs supports and extends the very early classification based on transmission electron microscopy (Ross and Long 1966; Ross 1967) but is now also based on a series of cell and molecular biological results: these LSMCs are the only SMCs which grow in situ in distinct monolayers of tight-packed monolayers and are very closely and stably connected by some endon-end and many vertical area adhaerens AJ-like structures (see below). Understandably, this latter special cell architectonic organization has not been noted in the numerous scanning electron microscopy preparations as these have only presented the outermost total cell surfaces of entire LSMC monolayers (see e.g., Tung and Fritz 1987; Palombi et al. 1992; Tripiciano et al. 1996, 1997, 1999; Romano et al. 2005; Losinno et al. 2016).

Clearly, these LSMCs are not just "myoid" (meaning only "looking like muscle" but not being a real muscle) as it had been proposed by Fawcett and co-workers (e.g., Fawcett et al. 1969; Fawcett 1994), who described them as "epithelial in shape and mode of association" with an "atypical shape" for a muscle cell. Gabella (1994) emphasized "an elongated spindle-shape" and a certain range of volume $\left(\mu \mathrm{m}^{3}\right)$ to surface $\left(\mu \mathrm{m}^{2}\right)$ ratio as a further criterion for smooth muscle cells which, of course, is clearly exceeded by LSMCs. These cells are also not "fibroblastic" or "myofibroblastic" (for the specific derivation and definition of the term myofibroblast, see e.g., Gabbiani et al. 1971, 1972; Majno et al. 1971; Böck et al. 1972; Eddy et al. 1988; Tomasek et al. 2002; Hinz et al. 2007; Hinz 2016; see also ESM, SLC No. 2). They are indeed complete SMCs sensu stricto as our results show that they contain all essential SMC molecules and structures such as actin- and myosin-containing myofilaments, often even organized in muscle-characteristic paracrystalline bundle arrays, dense bodies, focal adhesions (for reviews, see Jockusch et al. 1995; Critchley 2004, Dubash et al. 2009), and - regionally more or less frequent-caveolae (see e.g., ESM, SLC No. 3c). In molecular terms, we have shown that they are rich in the specific SMC marker proteins, including SMA (Skalli et al. 1986) and the corresponding myosin light and heavy chains (for review, see Krendel and Mooseker 2005), smoothelin (cf. van der Loop et al. 1996, 1997; Wehrens et al. 1997; Niessen et al. 2005; van Eys et al. 2007), IFs containing desmin or vimentin or both (cf. Franke et al. 1980, 1989; Berner et al. 1981; Frank and Warren 1981; Gabbiani et al. 1981, 1982; Osborn et al. 1981, 1987; Quinlan and Franke 1982; Schmid et al. 1982; Travo et al. 1982), and many other SMCcharacteristic proteins (Table 1; for further references, see ESM, SLC No. 3a). These LSMCs also contain SMC-typical $\mathrm{Ca}^{2+}$-binding and $\mathrm{Ca}^{2+}$-regulator proteins, 

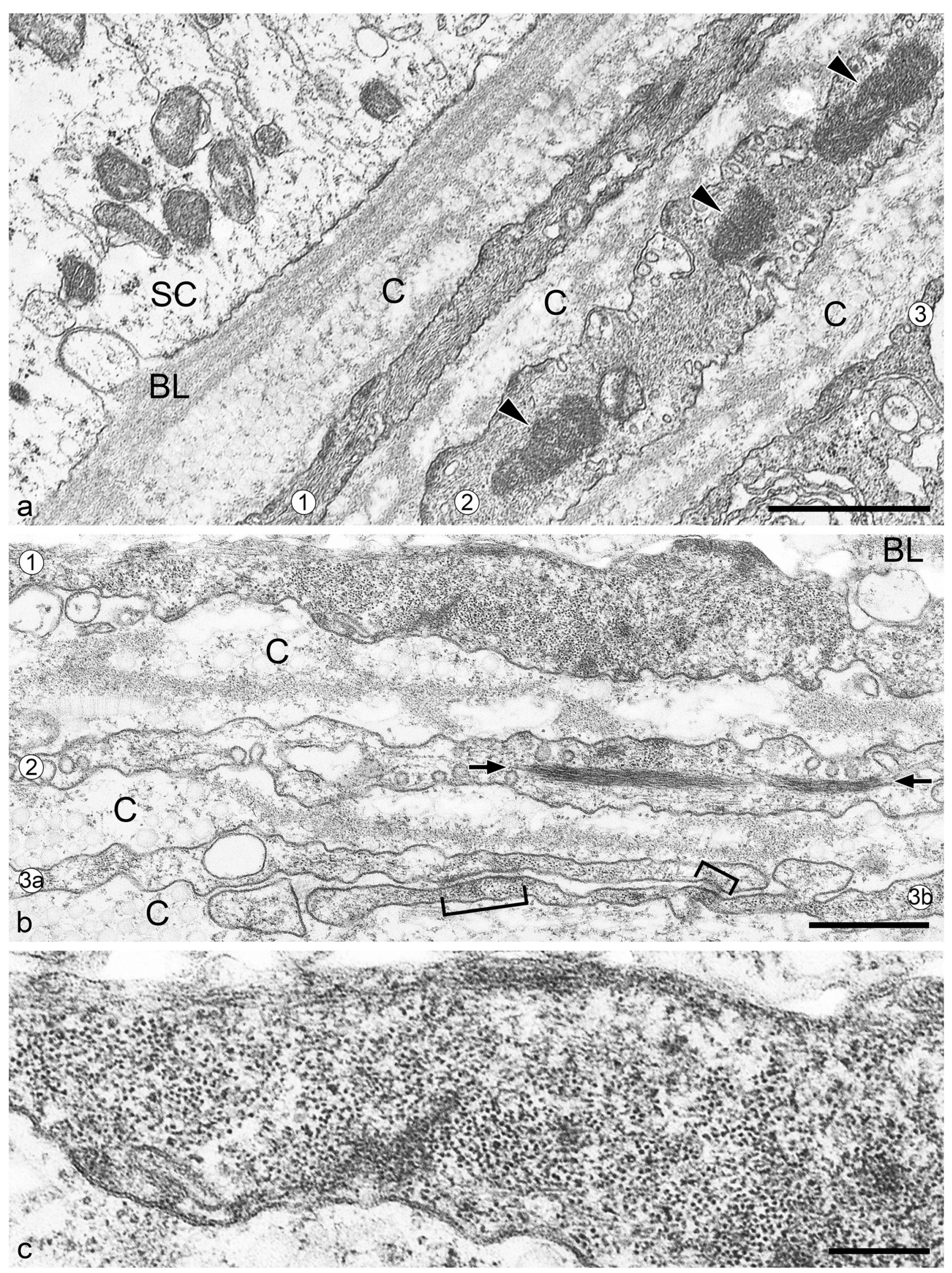
Fig. 15 Electron micrographs of ultrathin sections through bovine testicular tissue, showing details of the LSMC monolayers encasing the seminiferous tubules, interspersed with collagen (C) fiber-rich ECM layers (note that here almost all collagen fibers are cross-sectioned, i.e., orientated coaxially with the seminiferous tubules). a A Sertoli cell (SC) associated with the basal lamina (BL) which is attached to the first ECM layer (C, collagen fibrils). The following three layers of LSMCs shown here (nos. 1-3) are rich in myofilaments, intermediate-sized filaments, and cytoplasmic "dense bodies" (arrowheads). Note that most of the filaments in LSMC layer no. 1 extend in a direction different from that of the filaments seen in LSMC layer no. 2. b-d LSMCs rich in filament bundles are separated by layers of ECM. Note that here the LSMCs of all three layers (nos. 1-3a/b) contain cross-sectioned filament bundles running in the same direction as the specific seminiferous tubule: the major fibril bundle of LSMC layer no. 1 is shown at higher magnification in $\mathbf{c}$. The LSMC layer no. 2 contains in addition a circular peritubular fiber bundle (arrows). c Note the high-packing density of the ca. 6-nm-thick actin filaments, most of them arranged in paracrystalline arrays and sparse actomyosin filaments of ca. $12 \mathrm{~nm}$ diameter. Note also the close association of such filaments with focal adhesions and cytoplasmic plaques of cell-cell junctions (denoted by brackets in LSMC layer no. $3 \mathrm{a} / \mathrm{b}$ of $\mathbf{b}$ ). Bars $1 \mu \mathrm{m}(\mathbf{a}), 500 \mathrm{~nm}(\mathbf{b}), 200 \mathrm{~nm}(\mathbf{c})$

including calponin, caldesmon, and $\operatorname{SM} 22 \alpha$ (for references, see ESM, SLC No. 3b).

Some previous authors had already called these peritubular wall cells "SMCs" on the basis of positive reactions of one or a few SMC marker molecules such as SM- $\alpha$-actin, desmin, or a SM-myosin chain (e.g., Virtanen et al. 1986; Palombi et al. 1992; Romano et al. 2007). This, however, is an insufficient basis for any cell type identification and classification since the synthesis of just one or a few individual protein(s) does not define a special cell type in various tissues (there are several kinds of cells in non-SM tissues which are positive for one or a few SMC markers).

\section{LSMCs are among the thinnest mammalian cells growing in tissues}

Large parts of the peritubular wall LSMCs are remarkably thin (cytoplasmic distance between inner membrane surface-toinner membrane surface in the range of 30-100 $\mathrm{nm}$ ) and thus free of cell organelles and large vesicles or molecular aggregates. As mitochondria are apparently excluded from such very thin and often very large lamellar regions, the metabolic conditions in these cell parts seem to be rather special. To the best of our knowledge, these very flat LSMC regions are among the thinnest cytoplasmic regions so far noted in a mammalian tissue in situ, markedly thinner than, for example, the protrusions of specific bone marrow or cardiac valvular cells in situ or in cell cultures (e.g., Wuchter et al. 2007; Barth et al. 2009, 2012). Even thinner extended cytoplasmic regions of only 11-16 nm inner cytoplasmic thickness - but stabilized by special membrane-to-membrane columella structures- have been shown, to the best of our knowledge, in some cultured marsupial cells (cf. Franke et al. 1978b).

\section{Formation and stabilization of lateral connections in LSMc monolayers by vertical AJs in overlapping (ASA) thin lamelliform protrusions-a novel architectonic principle}

In the specific LSMC monolayers, adjacent cells are laterally connected by some sparse membrane-membrane contacts end-on-end. In addition, however, we have found that laterally adjacent LSMCs are further and more frequently connected by clusters of cell-cell contact structures of cadherin-11-based AJs located in an ASA arrangement of thin overlapping, lamelliform-like cell protrusions. In such - often very large-AJ-rich lamellar regions, the two plasma membranes are very close to each other and are stably anchored in a special type of cytoplasmic membrane-attached $\beta$-catenin-rich plaques. Clearly, the large majority of these LSMC-AJs is based on cadherin-11 (for rat testes, see also Johnson and Boekelheide 2002a, b), understandably as this type II cadherin is the major and characteristic "mesenchymal AJ-marker glycoprotein" (Okazaki et al. 1994; Hoffmann and Balling 1995; Kimura et al. 1995; Simonneau et al. 1995; Alimperti et al. 2014; see also ESM, SLC No. 4).

In addition, we have also found P-cadherin in LSMCs of peritubular walls but cannot yet decide whether this cadherin occurs only in a specific AJ subtype or whether AJs exist that contain both cadherin-11 and P-cadherin (for adhering junction heterocomplexes, see also Straub et al. 2011). In general, our immunocytochemical detection and localization of P-cadherin in peritubular wall cells is surprising as this cadherin is especially known from its occurrence in various kinds of epithelial cells and tumors derived therefrom (for references see, e.g., Nose and Takeichi 1986; Johnson et al. 1993; Wu et al. 1993; Furukawa et al. 1997). Our finding, however, appears to correspond, however, to the reports of Lin and DePhilip (1996a, b) that in murine testis, P-cadherin would occur only in Sertoli cells until postnatal day 8 but that subsequently de novo synthesis of P-cadherin is detectable only in LSMCs of peritubular walls after day 15 and in the adult animal.

\section{Studies using cell cultures containing LSMC-derived cells}

Certainly, it is experimentally not easy to isolate, enrich, and purify LSMCs and to let them grow and proliferate to confluent and junction-connected monolayer cultures corresponding 


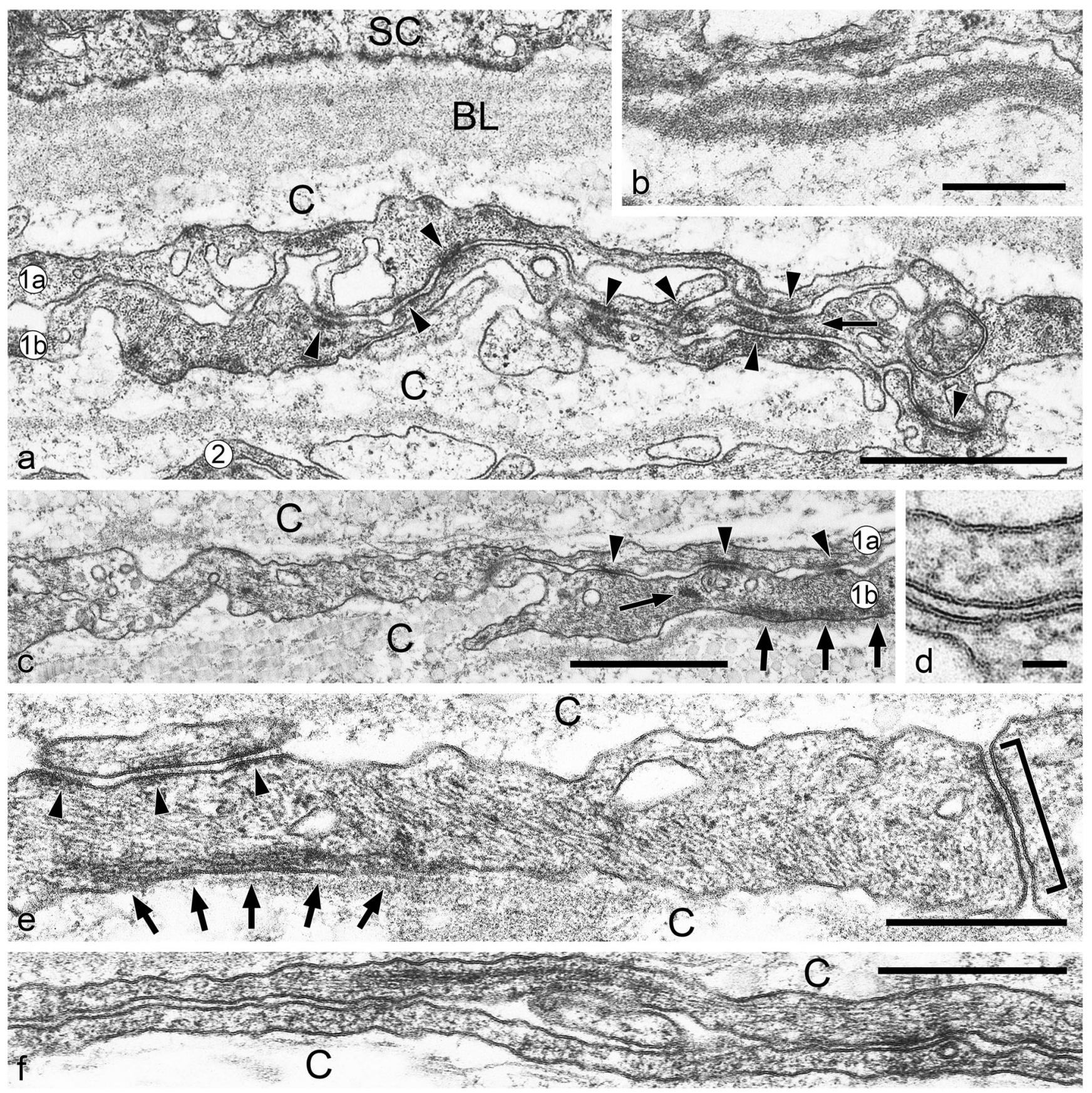

Fig. 16 Electron micrographs of ultrathin sections through peritubular walls of seminiferous tubules of bovine $(\mathbf{a}, \mathbf{c}-\mathbf{f})$ and porcine $(\mathbf{b})$ testes, showing LSMC layers with various ultrastructural forms of cell-cell junctions of the adherens junction (AJ) type. a, b The basal lamina (BL) is associated with the Sertoli cell (SC) and the first ECM layer (C, collagen fibrils), followed by an extended overlapping region of two neighboring cells of the first LSMC (nos. 1a and 1b) layer (note that in some species, i.e., in boar, frequent BL branching structures are seen, b). Note the numerous AJs (arrowheads) connecting overlapping lamellar protrusions of adjacent LSMCs in the same layer (nos. 1a and 1b). Similarly, appearing plaques of adjacent cells may also occur at cell-cell invaginations (e.g., at the arrow in the right). c, $\mathbf{d}$ Other regions of LSMC layers show clusters of AJs (arrowheads) as well as of focal adhesions (arrows) and individual dense bodies (thin arrow in $\mathbf{c}$ ). $\mathbf{d}$ High resolution of an AJtype cell-cell contact region without a visible electron-dense cytoplasmic plaque. e A special subform of plaque-anchored AJs (denoted by arrowheads in the upper left region) as well as a more extended end-on-end AJ (bracket on the right hand side) are seen as well as an extended focal adhesion in the lower left hand region (arrows). $\mathbf{f}$ Regions of overlapping flat LSMC processus, with longitudinally sectioned, i.e., circular, peritubular orientated filament bundles. Note that the plasma membranes of these cell portions are rather closely associated with each other over an extended, partly AJ-resembling region as characteristic also for areae adhaerentes. Bars $1 \mu \mathrm{m}(\mathbf{a}, \mathbf{c}), 500 \mathrm{~nm}(\mathbf{b}, \mathbf{e}, \mathbf{f}), 50 \mathrm{~nm}(\mathbf{d})$ 

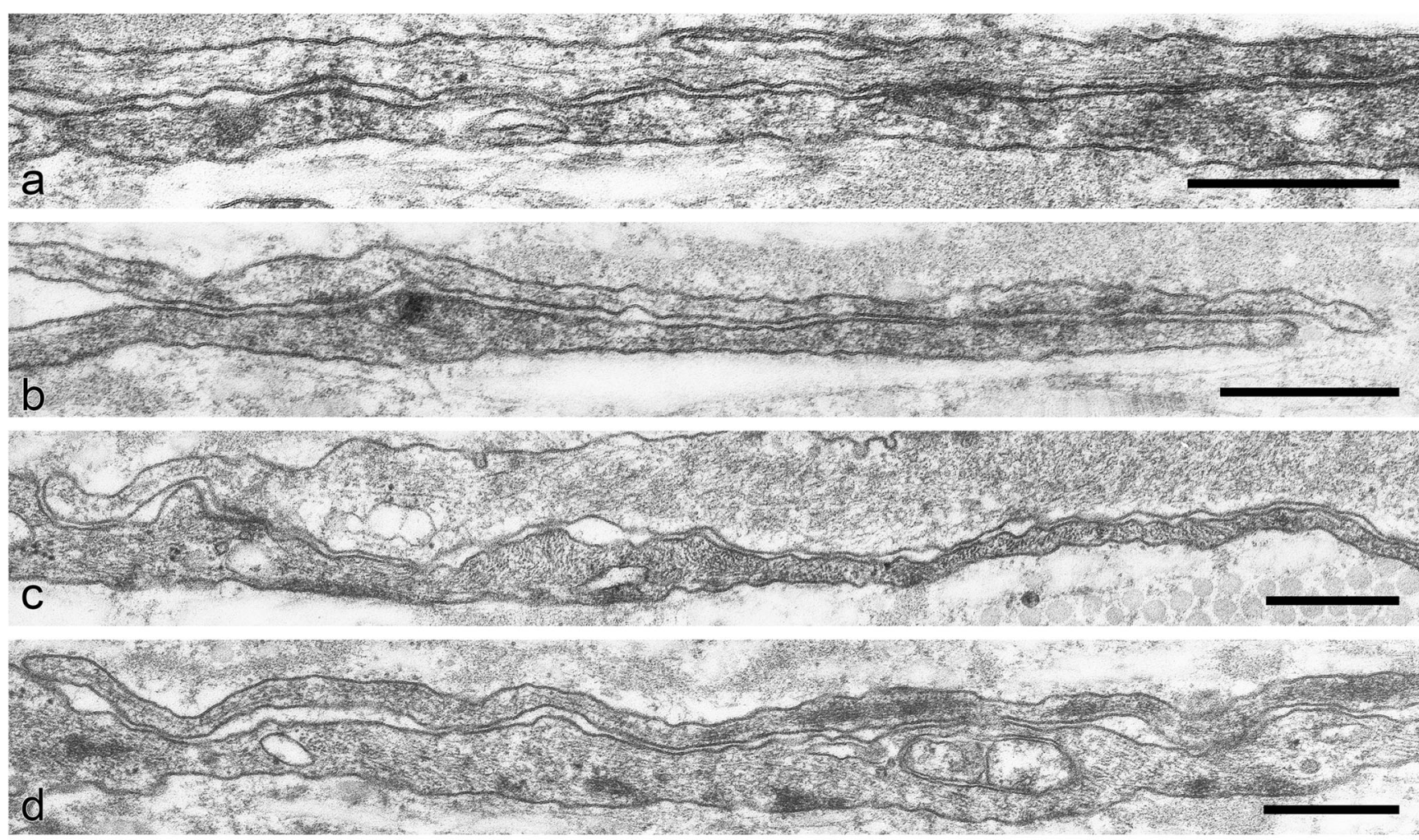

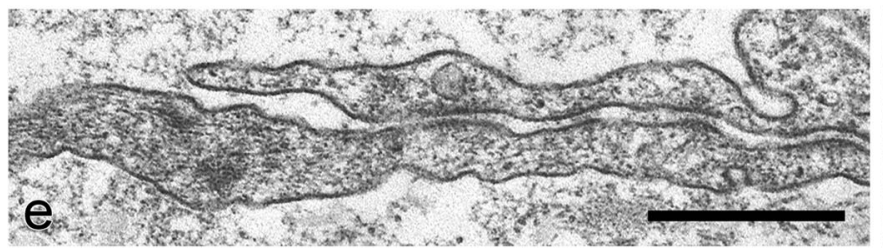

Fig. 17 Electron micrographs of ultrathin sections through peritubular walls of seminiferous tubules of bovine testes, showing LSMC layers with various ultrastructural forms of vertical cell-cell junctions of the adherens junction (AJ) type in extended overlapping regions (alter super alterum). These membrane-membrane complexes connect adjacent

to the peritubular wall SMCs in situ. Nevertheless, many reports on cultures of such cells have been published in the past decades, some of them as co-cultures or as interaction cultures with other-notably Sertoli — cells. Such cultured derivatives have in particular been used for the identification and/or functional elucidation of signaling and other interactions with Sertoli cells (e.g., Tung and Fritz 1980; Albrecht et al. 2006; Schell et al. 2008; Albrecht 2009; Mayerhofer 2013; see also ESM, SLC No. 5). Such studies have, for example, led to the discovery of dynamic LSMC components such as endothelin1, decorin, biglycan, fibronectin, Toll-like receptors, pigment epithelium-derived factor, and many more.

On the other hand, a number of researchers have reported cultures enriched in LSMCs by various isolation protocols, including co-cultures of LSMCs and Sertoli cells for example. While such cultures could be shown to synthesize the one or other typical secretory compound, the general value of such cultures is biologically not satisfactory: They appear to grow

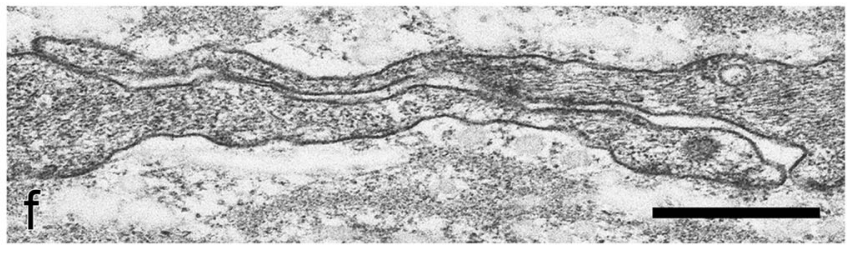

monolayer cells and contribute to closure of the peritubular wall structure against translocations of cells, particles, and large molecular complexes. Note also that some of these lamellar processes of LSMCs are very thin. Bars $500 \mathrm{~nm}$

in culture in a form very different from the typical LSMC morphology in situ. In particular, in all cultures so far shown in the literature, the cells were not polygonal, not at all confluent, not connected by typical ASA-SMC junctions, and not associated with ECM structures on both sides (see ESM, SLC No. 5).

\section{Structures and functions of testicular peritubular walls in non-mammalian vertebrates}

So far, only limited molecular and cell biological information is available for corresponding cell types and tissues of the wide range of non-mammalian animals, including species with seasonal fertility cycles or other changes. On the other hand, already rather early, some researchers had noted that apparently contractile LSMCs also occur in the peritubular walls of diverse lower vertebrates, in particular in birds, reptiles, and amphibia (see, e.g., Rothwell and Tingari 1973; Rothwell 1975; Unsicker 1974, 1975; Unsicker and Burnstock 1975; see also ESM, SLC 


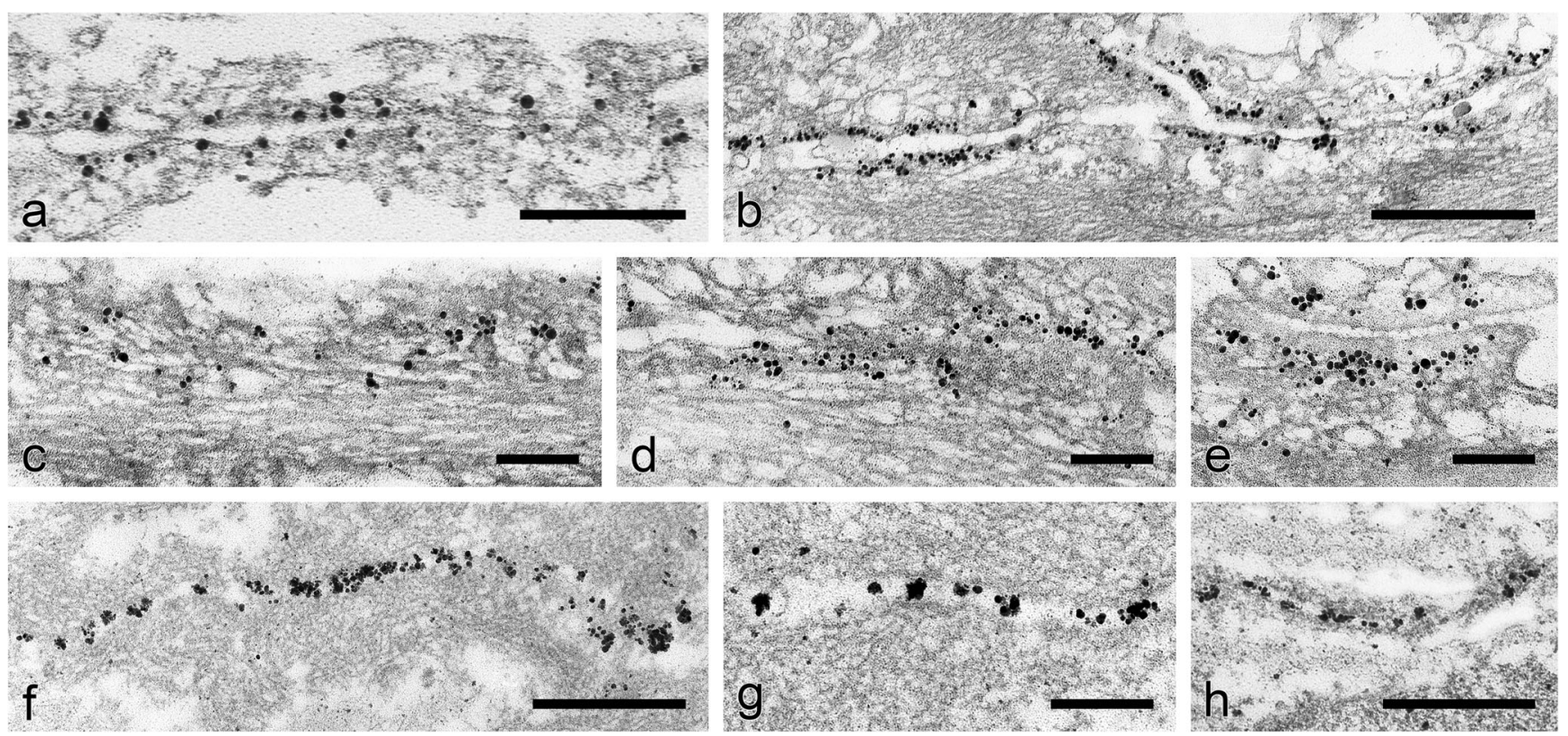

Fig. 18 Immunoelectron micrographs of ultrathin sections through bull testicular tissue, showing extended AJ regions connecting LSMCs in peritubular walls, labelled on the plaque-bearing, i.e., cytoplasmic side with antibodies against $\beta$-catenin $(\mathbf{a}, \mathbf{b})$ and protein myozap $(\mathbf{c}-\mathbf{e})$, visualized by immunogold labelling with silver enhancement. Further

No. 6), and the histology, the range of peritubular wall monolayers, and functional cell structures are surprisingly similar in a series of non-mammalian vertebrates (a correspondingly extensive biochemical, immunolocalization, and ultrastructural report of our group is currently in preparation).

Acknowledgements We thank Yvette Dörflinger for expert electron microscopic assistance and Ralf Zimbelmann for excellent technical assistance in biochemical work. This work is part of a Doctoral Thesis (Dr. rer. nat.) of the first author (Heidelberg University, Germany).

Open Access This article is distributed under the terms of the Creative Commons Attribution 4.0 International License (http:// creativecommons.org/licenses/by/4.0/), which permits unrestricted use, distribution, and reproduction in any medium, provided you give appropriate credit to the original author(s) and the source, provide a link to the Creative Commons license, and indicate if changes were made.

Publisher's Note Springer Nature remains neutral with regard to jurisdictional claims in published maps and institutional affiliations.

\section{References}

Achtstaetter T, Hatzfeld M, Quinlan RA, Parmelee DC, Franke WW (1986) Separation of cytokeratin polypeptides by gel electrophoretic and chromatographic techniques and their identification by immunoblotting. Meth Enzymol 134:355-371

Albrecht M (2009) Insights into the nature of human testicular peritubular cells. Ann Anat 191:532-540

Albrecht M, Rämsch R, Köhn FM, Schwarzer JU, Mayerhofer A (2006) Isolation and cultivation of human testicular peritubular cells: a new extensive immunolocalization results of the intermembrane AJ region have been obtained with antibodies against cadherin-11 (f-h), showing a distinct specific labelling of the extracellular intermembrane space of these AJs. Note also the dense associations of the thin cytoplasmic AJ plaques with filament bundles. Bars $200 \mathrm{~nm}(\mathbf{a}, \mathbf{d}, \mathbf{e}, \mathbf{g}), 500 \mathrm{~nm}(\mathbf{b}, \mathbf{c}, \mathbf{f}, \mathbf{h})$

model for the investigation of fibrotic processes in the human testis and male infertility. J Clin Endocrinol Metab 91:1956-1960

Alimperti S, You H, George T, Agarwal SK, Andreadis ST (2014) Cadherin-11 regulates both mesenchymal stem cell differentiation into smooth muscle cells and the development of contractile function in vivo. J Cell Sci 127:2627-2638

Anastasi G, Cutroneo G, Sidoti A, Rinaldi C, Bruschetta D, Rizzo G, D'Angelo R, Tarone G, Amato A, Favaloro A (2007) Sarcoglycan subcomplex expression in normal human smooth muscle. J Histochem Cytochem 55:831-843

Barth M, Schumacher H, Kuhn C, Akhyari P, Lichtenberg A, Franke WW (2009) Cordial connections: molecular ensembles and structures of adhering junctions connecting interstitial cells of cardiac valves in situ and in cell culture. Cell Tissue Res 337:63-77

Barth M, Rickelt S, Noffz E, Winter-Simanowski S, Niemann H, Akhyari P, Lichtenberg A, Franke WW (2012) The adhering junctions of valvular interstitial cells: molecular composition in fetal and adult hearts and the comings and goings of plakophilin-2 in situ, in cell culture and upon reassociation with scaffolds. Cell Tissue Res 348:295-307

Baumgarten HG, Hostein AF, Rosengren E (1971) Arrangement, ultrastructure, and adrenergic innervation of smooth musculature of the ductuli efferentes, ductus epididymidis and ductus deferens of man. Z Zellforsch 120:37-79

Bennett V, Healy J (2009) Membrane domains based on ankyrin and spectrin associated with cell-cell interactions. Cold Spring Harb Perspect Biol 1:a003012

Berner PF, Frank E, Holtzer H, Somlyo AP (1981) The intermediate filament proteins of rabbit vascular smooth muscle: immunofluorescent studies of desmin and vimentin. J Muscle Res Cell Motil 2:439-452

Böck P, Breitenecker G, Lunglmayr G (1972) Contractile fibroblasts (myofibroblasts) in the lamina propria of human seminiferous tubules. Z Zellforsch Mikrosk Anat 133:519-527

Bustos-Obregon E (1976) Ultrastructure and function of the lamina propria of mammalian seminiferous tubules. Andrologia 8:179-185

Byers SW, Sujarit S, Jegou B, Butz S, Hoschutzky H, Herrenknecht K, MacCalman C, Blaschuk OW (1994) Cadherins and cadherin- 
associated molecules in the developing and maturing rat testis. Endocrinology 134:630-639

Chakraborty J, Nelson L, Hjunjhunwala J, Young M, Kropp K (1976) Basal lamina of human seminiferous tubule - its role in material transport. Cell Tissue Res 174:261-271

Christl HW (1990) The lamina propria of vertebrate seminiferous tubules: a comparative light and electron microscopic investigation. Andrologia 22:85-94

Clermont Y (1958) Contractile elements in the limiting membrane of the seminiferous tubules of the rat. Exp Cell Res 15:438-440

Critchley DR (2004) Cytoskeletal proteins talin and vinculin in integrinmediated adhesion. Biochem Soc Trans 32:831-836

Culligan KG, Mackey AJ, Finn DM, Maguire PB, Ohlendieck K (1998) Role of dystrophin isoforms and associated proteins in muscular dystrophy (review). Int J Mol Med 2:639-648

Cyr DG, Blaschuk OW, Robaire B (1992) Identification and developmental regulation of cadherin messenger ribonucleic acids in the rat testis. Endocrinology 131:139-145

Cyr DG, Hermo L, Robaire B (1993) Developmental changes in epithelial cadherin messenger ribonucleic acid and immunocytochemical localization of epithelial cadherin during postnatal epididymal development in the rat. Endocrinology 132:1115-1124

De Kretser DM, Kerr JB, Paulsen CA (1975) The peritubular tissue in the normal and pathological human testis. An ultrastructural study. Biol Reprod 12:317-324

Domke LM (2018) Molecular and ultrastructural characteristics of adhering junctions and cytoskeletons in cells of the seminiferous tubules and the peritubular walls of mammalian testes. $\mathrm{PhD}$ Thesis. Combined Faculties for the Natural Sciences and for Mathematics, University of Heidelberg, Germany

Domke LM, Rickelt S, Dörflinger Y, Kuhn C, Winter-Simanowski S, Zimbelmann R, Rosin-Arbesfeld R, Heid H, Franke WW (2014) The cell-cell junctions of mammalian testes: I. The adhering junctions of the seminiferous epithelium represent special differentiation structures. Cell Tissue Res 357:645-665

Dubash AD, Menold MM, Samson T, Boulter E, Garcia-Mata R, Doughman R, Burridge K (2009) Chapter 1. Focal adhesions: new angles on an old structure. Int Rev Cell Mol Biol 277:1-65

Dym M (1975) Male reproductive system. In: Bloom W, Fawcett DW (eds) A textbook of histology. Saunders Company, Philadelphia, pp 805-857

Dym M, Fawcett DW (1970) The blood-testis barrier in the rat and the physiological compartmentation of the seminiferous epithelium. Biol Reprod 3:308-326

Eddy RJ, Petro JA, Tomasek JJ (1988) Evidence for the nonmuscle nature of the "myofibroblast" of granulation tissue and hypertrophic scar. An immunofluorescence study. Am J Pathol 130:252-260

Fawcett DW (1994) Male reproductive system. In: Fawcett DW, Raviola E (eds) Bloom and Fawcett, a textbook of histology, 12th edn. Chapman and Hall, New York, pp 768-815

Fawcett DW, Heidger PM, Leak LV (1969) Lymph vascular system of the interstitial tissue of the testis as revealed by electron microscopy. J Reprod Fertil 19:109-119

Frank ED, Warren L (1981) Aortic smooth muscle cells contain vimentin instead of desmin. Proc Natl Acad Sci U S A 78:3020-3024

Franke WW, Quinlan RA (1983) Intermediate filaments of the vascular wall. In: Schettler FG et al (eds) Atherosclerosis VI. Proceedings of the Sixth International Symposium on Atherosclerosis. SpringerVerlag, Berlin, pp 390-394

Franke WW, Grund C, Fink A, Weber K, Jockusch BM, Zentgraf H, Osborn M (1978a) Location of actin in the microfilament bundles associated with the junctional specializations between Sertoli cells and spermatids. Biol Cell 31:7-14

Franke WW, Grund C, Schmid E, Mandelkow E (1978b) Paracrystalline arrays of membrane-to-membrane cross bridges associated with the inner surface of plasma membrane. J Cell Biol 77:323-228
Franke WW, Grund C, Schmid E (1979) Intermediate-sized filaments present in Sertoli cells are of the vimentin type. Eur J Cell Biol 19: 269-275

Franke WW, Schmid E, Vandekerckhove J, Weber K (1980) A permanently proliferating rat vascular smooth muscle cell with maintained expression of smooth muscle characteristics, including actin of the vascular smooth muscle type. J Cell Biol 87:594-600

Franke WW, Moll R, Schiller DL, Schmid E, Kartenbeck J, Mueller H (1982a) Desmoplakins of epithelial and myocardial desmosomes are immunologically and biochemically related. Differentiation 23:115127

Franke WW, Schmid E, Schiller DL, Winter S, Jarasch E-D, Moll R, Denk H, Jackson B, Illmensee K (1982b) Differentiation-related patterns of expression of proteins of intermediate-sized filaments in tissues and cultured cells. Cold Spring Harb Symp Quant Biol 46:431-453

Franke WW, Jahn L, Knapp AC (1989) Cytokeratins and desmosomal proteins in certain epithelioid and nonepithelial cells. In: Osborn M, Weber K (eds) Cytoskeletal proteins in tumor diagnosis. Cold Spring Harbor Laboratory, New York, pp 151-172

Franke WW, Borrmann CM, Grund C, Pieperhoff S (2006) The area composita of adhering junctions connecting heart muscle cells of vertebrates. I. Molecular definition in intercalated disks of cardiomyocytes by immunoelectron microscopy of desmosomal proteins. Eur J Cell Biol 85:69-82

Franke WW, Heid H, Zimbelmann R, Kuhn C, Winter-Simanowski S, Dörflinger Y, Grund C, Rickelt S (2013) Transmembrane protein PERP is a component of tessellate junctions and of other junctional and non-junctional plasma membrane regions in diverse epithelial and epithelium-derived cells. Cell Tissue Res 353:99-115

Franke WW, Dörflinger Y, Kuhn C, Zimbelmann R, Winter-Simanowski S, Frey N, Heid H (2014) Protein LUMA is a cytoplasmic plaque constituent of various epithelial adherens junctions and composite junctions of myocardial intercalated disks: a unifying finding for cell biology and cardiology. Cell Tissue Res 357:159-172

Franke WW, Rickelt S, Zimbelmann R, Dörflinger Y, Kuhn C, Frey N, Heid H, Rosin-Arbesfeld R (2015) Striatins as plaque molecules of zonulae adhaerentes in simple epithelia, of tessellate junctions in stratified epithelia, of cardiac composite junctions and of various size classes of lateral adherens junctions in cultures of epitheliaand carcinoma-derived cells. Cell Tissue Res 359:779-797

Furukawa F, Fujii K, Horiguchi Y, Matsuyoshi N, Fujita M, Toda K, Imamura S, Wakita H, Shirahama S, Takigawa M (1997) Roles of E- and P-cadherin in the human skin. Microsc Res Tech 38:343-352

Gabbiani G, Ryan GB, Majne G (1971) Presence of modified fibroblasts in granulation tissue and their possible role in wound contraction. Experientia 27:549-550

Gabbiani G, Hirschel BJ, Ryan GB, Statkov PR, Majno G (1972) Granulation tissue as a contractile organ. A study of structure and function. J Exp Med 135:719-734

Gabbiani G, Schmid E, Winter S, Chaponnier C, de Ckhastonay C, Vandekerckhove J, Weber K, Franke WW (1981) Vascular smooth muscle cells differ from other smooth muscle cells: predominance of vimentin filaments and a specific alpha-type actin. Proc Natl Acad Sci U S A 78:298-302

Gabbiani G, Rungger-Brändle E, de Chastonay C, Franke WW (1982) Vimentin-containing smooth muscle cells in aortic intimal thickening after endothelial injury. Lab Invest 47:265-269

Gabella G (1994) Structure of smooth muscles. In: Szekeres L, Papp JG (eds) Pharmacology of smooth muscle. Handbook of experimental pharmacology, vol 111. Springer, Berlin, pp 3-34

Galdieri M, Ricci G (1998) Characterization of different cell populations isolated from rat testis peritubular cells. Differentiation 63:13-19

Gard DL, Lazarides E (1980) The synthesis and distribution of desmin and vimentin during myogenesis in vitro. Cell 19:263-275 
Guttman JA, Takai Y, Vogl AW (2004) Evidence that tubulobulbar complexes in the seminiferous epithelium are involved with internalization of adhesion junctions. Biol Reprod 71:548-559

Halayko AJ, Stelmack GL (2005) The association of caveolae, actin, and the dystrophin-glycoprotein complex: a role in smooth muscle phenotype and function? Can J Physiol Pharmacol 83:877-891

Hargrove JL, MacIndoe JH, Ellis LC (1977) Testicular contractile cells and sperm transport. Fertil Steril 28:1146-1157

Heid H, Figge U, Winter S, Kuhn C, Zimbelmann R, Franke W (2002) Novel actin-related proteins Arp-T1 and Arp-T2 as components of the cytoskeletal calyx of the mammalian sperm head. Exp Cell Res 279:177-187

Hess H, Heid H, Franke WW (1993) Molecular characterization of mammalian cylicin, a basic protein of the sperm head cytoskeleton. J Cell Biol 122:1043-1052

Hess H, Heid H, Zimbelmann R, Franke WW (1995) The protein complexity of the cytoskeleton of bovine and human sperm heads: the identification and characterization of cylicin II. Exp Cell Res 218: 174-182

Hinz B (2016) Myofibroblasts. Exp Eye Res 142:56-70

Hinz B, Phan SH, Thannickal VJ, Galli A, Bochaton-Piallat ML, Gabbiani G (2007) The myofibroblast: one function, multiple origins. Am J Pathol 170:1807-1816

Hoffmann I, Balling R (1995) Cloning and expression analysis of a novel mesodermally expressed cadherin. Dev Biol 169:337-346

Hovatta O (1972) Contractility and structure of adult rat seminiferous tubules in organ culture. Z Zellforsch Mikrosk Anat 130:171-179

Inagaki M, Irie K, Ishizaki H, Tanaka-Okamoto M, Miyoshi J, Takai Y (2006) Role of cell adhesion molecule nectin-3 in spermatid development. Genes Cells 11:1125-1132

Ito K, Kimura S, Ozasa S, Matsukura M, Ikezawa M, Yoshioka K, Ueno H, Suzuki M, Araki K, Yamamura K, Miwa T, Dickson G, Thomas GD, Miike T (2006) Smooth muscle-specific dystrophin expression improves aberrant vasoregulation in mdx mice. Hum Mol Genet 15: 2266-2275

Jockusch BM, Bubeck P, Giehl K, Kroemker M, Moschner J, Rothkegel M, Rüdiger M, Schlüter K, Stanke G, Winkler J (1995) The molecular architecture of focal adhesions. Annu Rev Cell Dev Biol 11: $379-416$

Johnson KJ, Boekelheide K (2002a) Dynamic testicular adhesion junctions are immunologically unique. I. Localization of p120 catenin in rat testis. Biol Reprod 66:983-9912002

Johnson KJ, Boekelheide K (2002b) Dynamic testicular adhesion junctions are immunologically unique. II. Localization of classic cadherins in rat testis. Biol Reprod 66:992-1000

Johnson KR, Lewis JE, Li D, Wahl J, Soler AP, Knudsen KA, Wheelock MJ (1993) P- and E-cadherin are in separate complexes in cells expressing both cadherins. Exp Cell Res 207:252-260

Kimura Y, Matsunami H, Inoue T, Shimamura K, Uchida N, Ueno T, Miyazaki T, Takeichi M (1995) Cadherin-11 expressed in association with mesenchymal morphogenesis in the head, somite, and limb bud of early mouse embryos. Dev Biol 169:347-358

Kormano M, Hovatta O (1972) Contractility and histochemistry of the myoid cell layer of the rat seminiferous tubules during postnatal development. Z Anat Entwicklungsgesch 137:239-248

Koster J, Geerts D, Favre B, Borradori L, Sonnenberg A (2003) Analysis of the interactions between BP180, BP230, plectin and the integrin alpha6beta4 important for hemidesmosome assembly. J Cell Sci 116:387-399

Krendel M, Mooseker MS (2005) Myosins: tails (and heads) of functional diversity. Physiology (Bethesda) 20:239-251

Langbein L, Grund C, Kuhn C, Praetzel S, Kartenbeck J, Brandner JM, Moll I, Franke WW (2002) Tight junctions and compositionally related junctional structures in mammalian stratified epithelia and cell cultures derived therefrom. Eur J Cell Biol 81:419-435
Leeson CR, Forman DE (1981) Postnatal development and differentiation of contractile cells within the rabbit testis. J Anat 132:491-511

Leeson CR, Leeson TS (1963) The postnatal development and differentiation of the boundary tissue of the seminiferous tubule of the rat. Anat Rec 147:243-259

Lin LH, DePhilip RM (1996a) Differential expression of placental (P)cadherin in sertoli cells and peritubular myoid cells during postnatal development of the mouse testis. Anat Rec 244:155-164

Lin LH, DePhilip RM (1996b) Sex-dependent expression of placental (P)-cadherin during mouse gonadogenesis. Anat Rec 246:535-544

Longo FJ, Krohne G, Franke WW (1987) Basic proteins of the perinuclear theca of mammalian spermatozoa and spermatids: a novel class of cytoskeletal elements. J Cell Biol 105:1105-1120

Losinno AD, Morales A, Fernandez D, Lopez LA (2012) Peritubular myoid cells from rat seminiferous tubules contain actin and myosin filaments distributed in two independent layers. Biol Reprod 86:150 151-158

Losinno AD, Sorrivas V, Ezquer M, Ezquer F, Lopez LA, Morales A (2016) Changes of myoid and endothelial cells in the peritubular wall during contraction of the seminiferous tubule. Cell Tissue Res 365:425-435

Maekawa M, Kamimura K, Nagano T (1996) Peritubular myoid cells in the testis: their structure and function. Arch Histol Cytol 59:1-13

Majno G, Gabbiani G, Hirschel BJ, Ryan GB, Statkov PR (1971) Contraction of granulation tissue in vitro: similarity to smooth muscle. Science 173:548-550

Mayerhofer A (2013) Human testicular peritubular cells: more than meets the eye. Reproduction 145:R107-R116

Meng W, Takeichi M (2009) Adherens junction: molecular architecture and regulation. Cold Spring Harb Perspect Biol 1:a002899

Newton SC, Blaschuk OW, Millette CF (1993) N-cadherin mediates Sertoli cell-spermatogenic cell adhesion. Dev Dyn 197:1-13

Niessen P, Rensen S, Van Deursen J, De Man J, De Laet A, Vanderwinden JM, Wedel T, Baker D, Doevendans P, Hofker M, Gijbels M, Van Eys G (2005) Smoothelin-a is essential for functional intestinal smooth muscle contractility in mice. Gastroenterology 129:1592-1601

North AJ, Galazkiewicz B, Byers TJ, Glenney JR Jr, Small JV (1993) Complementary distributions of vinculin and dystrophin define two distinct sarcolemma domains in smooth muscle. J Cell Biol 120: $1159-1167$

Nose A, Takeichi M (1986) A novel cadherin cell adhesion molecule: its expression patterns associated with implantation and organogenesis of mouse embryos. J Cell Biol 103:2649-2658

Okazaki M, Takeshita S, Kawai S, Kikuno R, Tsujimura A, Kudo A, Amann E (1994) Molecular cloning and characterization of OBcadherin, a new member of cadherin family expressed in osteoblasts. J Biol Chem 269:12092-12098

Osborn M, Ludwig-Festl M, Weber K, Bignami A, Dahl D, Bayreuther K (1981) Expression of glial and vimentin type intermediate filaments in cultures derived from human glial material. Differentiation 19: $161-167$

Osborn M, Caselitz J, Puschel K, Weber K (1987) Intermediate filament expression in human vascular smooth muscle and in arteriosclerotic plaques. Virchows Arch A Pathol Anat Histopathol 411:449-458

Owaribe K, Kartenbeck J, Stumpp S, Magin TM, Krieg T, Diaz LA, Franke WW (1990) The hemidesmosomal plaque. I. Characterization of a major constituent protein as a differentiation marker for certain forms of epithelia. Differentiation 45:207-220

Owaribe K, Nishizawa Y, Franke WW (1991) Isolation and characterization of hemidesmosomes from bovine corneal epithelial cells. Exp Cell Res 192:622-630

Ozaki-Kuroda K, Nakanishi H, Ohta H, Tanaka H, Kurihara H, Mueller S, Irie K, Ikeda W, Sakai T, Wimmer E, Nishimune Y, Takai Y (2002) Nectin couples cell-cell adhesion and the actin scaffold at heterotypic testicular junctions. Curr Biol 12:1145-1150 
Palombi F, Farini D, Salanova M, de Grossi S, Stefanini M (1992) Development and cytodifferentiation of peritubular myoid cells in the rat testis. Anat Rec 233:32-40

Paranko J, Virtanen I (1986) Epithelial and mesenchymal cell differentiation in the fetal rat genital ducts: changes in the expression of cytokeratin and vimentin type of intermediate filaments and desmosomal plaque proteins. Dev Biol 117:135-145

Peitsch WK, Grund C, Kuhn C, Schnölzer M, Spring H, Schmelz M, Franke WW (1999) Drebrin is a widespread actin-associating protein enriched at junctional plaques, defining a specific microfilament anchorage system in polar epithelial cells. Eur J Cell Biol 78:767-778

Peitsch WK, Hofmann I, Prätzel S, Grund C, Kuhn C, Moll I, Langbein L, Franke WW (2001) Drebrin particles: components in the ensemble of proteins regulating actin dynamics of lamellipodia and filopodia. Eur J Cell Biol 80:567-579

Peitsch WK, Hofmann I, Bulkescher J, Hergt M, Spring H, Bleyl U, Goerdt S, Franke WW (2005) Drebrin, an actin-binding, cell type characteristic protein: induction and localization in epithelial skin tumors and cultured keratinocytes. J Invest Dermatol 125:761-774

Perez TD, Nelson WJ (2004) Cadherin adhesion: mechanisms and molecular interactions. In: Behrens J, Nelson WJ (eds) Cell adhesion. Handb Exp Pharmacol 165. Springer, Berlin, pp 3-21

Pieperhoff S, Rickelt S, Heid H, Claycomb WC, Zimbelmann R, Kuhn C, Winter-Simanowski S, Frey N, Franke WW (2012) The plaque protein myozap identified as a novel major component of adhering junctions in endothelia of the blood and the lymph vascular systems. J Cell Mol Med 16:1709-1719

Quinlan RA, Franke WW (1982) Heteropolymer filaments of vimentin and desmin in vascular smooth muscle tissue and cultured baby hamster kidney cells demonstrated by chemical crosslinking. Proc Natl Acad Sci U S A 79:3452-3456

Quinlan RA, Franke WW (1983) Molecular interactions in intermediatesized filaments revealed by chemical cross-linking. Heteropolymers of vimentin and glial filament protein in cultured human glioma cells. Eur J Biochem 132:477-484

Quinlan RA, Schiller DL, Hatzfeld M, Achtstätter T, Moll R, Jorcano JL, Magin TM, Franke WW (1985) Patterns of expression and organization of cytokeratin intermediate filaments. Ann N Y Acad Sci 455: 282-306

Ramírez-Sánchez I, Rosas-Vargas H, Ceballos-Reyes G, Salamanca F, Coral-Vázquez RM (2005) Expression analysis of the SG-SSPN complex in smooth muscle and endothelial cells of human umbilical cord vessels. J Vasc Res 42:1-7

Rickelt S, Rizzo S, Dörflinger Y, Zentgraf H, Basso C, Gerosa G, Thiene G, Moll R, Franke WW (2010) A novel kind of tumor typecharacteristic junction: plakophilin-2 as a major protein of adherens junctions in cardiac myxomata. Mod Pathol 23:1429-1437

Rickelt S, Kuhn C, Winter-Simanowski S, Zimbelmann R, Frey N, Franke WW (2011) Protein myozap-a late addition to the molecular ensembles of various kinds of adherens junctions. Cell Tissue Res 346:347-359

Romano F, Tripiciano A, Muciaccia B, De Cesaris P, Ziparo E, Palombi F, Filippini A (2005) The contractile phenotype of peritubular smooth muscle cells is locally controlled: possible implications in male fertility. Contraception 72:294-297

Romano F, Gambara G, De Cesaris P, Ziparo E, Palombi F, Filippini A (2007) Endothelin induces functional hypertrophy of peritubular smooth muscle cells. J Cell Physiol 212:264-273

Roosen-Runge EC (1951) Motions of the seminiferous tubules of rat and dog. Anat Rec 109:413

Ross MH (1967) The fine structure and development of the peritubular contractile cell component in the seminiferous tubules of the mouse. Am J Anat 121:523-557

Ross MH, Long IR (1966) Contractile cells in human seminiferous tubules. Science 153:1271-1273
Rothwell B (1975) Designation of the cellular component of the peritubular boundary tissue of the seminiferous tubule in the testis of the fowl (Gallus domesticus). Br Poult Sci 16:527-529

Rothwell B, Tingari MD (1973) The ultrastructure of the boundary tissue of the seminiferous tubule in the testis of the domestic fowl (Gallus domesticus). J Anat 114:321-328

Schell C, Albrecht M, Mayer C, Schwarzer JU, Frungieri MB, Mayerhofer A (2008) Exploring human testicular peritubular cells: identification of secretory products and regulation by tumor necrosis factor-alpha. Endocrinology 149:1678-1686

Schmid E, Osborn M, Rungger-Brändle E, Gabbiani G, Weber K, Franke WW (1982) Distribution of vimentin and desmin filaments in smooth muscle tissue of mammalian and avian aorta. Exp Cell Res 137:329-340

Seeger TS, Frank D, Rohr C, Will R, Just S, Grund C, Lyon R, Luedde M, Koegl M, Sheikh F, Rottbauer W, Franke WW, Katus HA, Olson EN, Frey N (2010) Myozap, a novel intercalated disc protein, activates serum response factor-dependent signaling and is required to maintain cardiac function in vivo. Circ Res 106:880-890

Shi SR, Key ME, Kalra KL (1991) Antigen retrieval in formalin-fixed, paraffin-embedded tissues: an enhancement method for immunohistochemical staining based on microwave oven heating of tissue sections. J Histochem Cytochem 39:741-748

Simonneau L, Kitagawa M, Suzuki S, Thiery JP (1995) Cadherin 11 expression marks the mesenchymal phenotype: towards new functions for cadherins? Cell Adhes Commun 3:115-130

Skalli O, Ropraz P, Trzeciak A, Benzonana G, Gillessen D, Gabbiani G (1986) A monoclonal antibody against alpha-smooth muscle actin: a new probe for smooth muscle differentiation. J Cell Biol 103:27872796

Soellner P, Quinlan RA, Franke WW (1985) Identification of a distinct soluble subunit of an intermediate filament protein: tetrameric vimentin from living cells. Proc Natl Acad Sci U S A 82:7929-7933

Sonnenberg A, Calafat J, Janssen H, Daams H, van der Raaij-Helmer LMH, Falcioni R, Kennel SJ, Aplin JD, Baker J, Loizidou M, Garrod D (1991) Integrin alpha 6/beta 4 complex is located in hemidesmosomes, suggesting a major role in epidermal cellbasement membrane adhesion. J Cell Biol 113:907-917

Spruill WA, Zysk JR, Tres LL, Kierszenbaum AL (1983) Calcium/ calmodulin-dependent phosphorylation of vimentin in rat Sertoli cells. Proc Natl Acad Sci U S A 80:760-764

Sterk LM, Geuijen CA, Oomen LC, Calafat J, Janssen H, Sonnenberg A (2000) The tetraspan molecule CD151, a novel constituent of hemidesmosomes, associates with the integrin alpha6beta4 and may regulate the spatial organization of hemidesmosomes. J Cell Biol 149:969-982

Straub BK, Rickelt S, Zimbelmann R, Grund C, Kuhn C, Iken M, Ott M, Schirmacher P, Franke WW (2011) E-N-cadherin heterodimers define novel adherens junctions connecting endoderm-derived cells. J Cell Biol 195:873-887

Takai Y, Nakanishi H (2003) Nectin and afadin: novel organizers of intercellular junctions. J Cell Sci 116:17-27

Takeichi M (1990) Cadherins: a molecular family important in selective cell-cell adhesion. Annu Rev Biochem 59:237-252

Tomasek JT, Gabbiani G, Hinz B, Chaponnier C, Brown RA (2002) Myofibroblasts and mechano-regulation of connective tissue remodelling. Nat Rev Mol Cell Biol 3:349-363

Travo P, Weber K, Osborn M (1982) Co-existence of vimentin and desmin type intermediate filaments in a subpopulation of adult rat vascular smooth muscle cells growing in primary culture. Exp Cell Res 139:87-94

Tripiciano A, Filippini A, Giustiniani Q, Palombi F (1996) Direct visualization of rat peritubular myoid cell contraction in response to endothelin. Biol Reprod 55:25-31 
Tripiciano A, Palombi F, Ziparo E, Filippini A (1997) Dual control of seminiferous tubule contractility mediated by ETA and ETB endothelin receptor subtypes. FASEB J 11:276-286

Tripiciano A, Peluso C, Morena AR, Palombi F, Stefanini M, Ziparo E, Yanagisawa M, Filippini A (1999) Cyclic expression of endothelinconverting enzyme-1 mediates the functional regulation of seminiferous tubule contraction. J Cell Biol 145:1027-1038

Tung PS, Fritz IB (1980) Interactions of Sertoli cells with myoid cells in vitro. Biol Reprod 23:207-217

Tung PS, Fritz IB (1987) Morphogenetic restructuring and formation of basement membranes by Sertoli cells and testis peritubular cells in co-culture: inhibition of the morphogenetic cascade by cyclic AMP derivatives and by blocking direct cell contact. Dev Biol 120:139-153

Uematsu J, Nishizawa Y, Sonnenberg A, Owaribe K (1994) Demonstration of type II hemidesmosomes in a mammary gland epithelial cell line, BMGE-H. J Biochem 115:469-476

Unsicker K (1974) Contractile filamentous structures in Sertoli cells of the Greek tortoise (Testudo graeca)? Experientia 30:272-273

Unsicker K (1975) Fine structure of the male genital tract and kidney in the anura Xenopus laevis Daudin, Rana temporaria L. and Bufo Bufo L. under normal and experimental conditions. I. Testicular interstitial tissue and seminal efferent ducts. Cell Tissue Res 158: $215-240$

Unsicker K, Burnstock G (1975) Myoid cells in the peritubular tissue (Lamina propria) of the reptilian testis. Cell Tissue Res 163:545-560

van der Loop FT, Schaart G, Timmer ED, Ramaekers FC, Van Eys GJ (1996) Smoothelin, a novel cytoskeletal protein specific for smooth muscle cells. J Cell Biol 134:401-411

van der Loop FT, Gabbiani G, Kohnen G, Ramaekers FC, Van Eys GJ (1997) Differentiation of smooth muscle cells in human blood vessels as defined by smoothelin, a novel marker for the contractile phenotype. Arterioscler Thromb Vasc Biol 17:665-671

van Eys GJ, Niessen PM, Rensen SS (2007) Smoothelin in vascular smooth muscle cells. Trends Cardiovasc Med 17:26-30

Van Muijen GN, Ruiter DJ, Warnaar SO (1987) Coexpression of intermediate filament polypeptides in human fetal and adult tissues. Lab Invest 57:359-369

van Vorstenbosch CJ, Colenbrander B, Wensing CJ, Ramaekers FC, Vooijs GP (1984) Cytoplasmic filaments in fetal and neonatal pig testis. Eur J Cell Biol 34:292-299

Vannucchi MG, Zardo C, Corsani L, Faussone-Pellegrini MS (2002) Interstitial cells of Cajal, enteric neurons, and smooth muscle and myoid cells of the murine gastrointestinal tract express full-length dystrophin. Histochem Cell Biol 118:449-457

Vestweber D, Kemler R (1984) Some structural and functional aspects of the cell adhesion molecule uvomorulin. Cell Differ 15:269-273

Virtanen I, Kallajoki M, Narvanen O, Paranko J, Thornell LE, Miettinen M, Lehto VP (1986) Peritubular myoid cells of human and rat testis are smooth muscle cells that contain desmin-type intermediate filaments. Anat Rec 215:10-20
Vlahova L, Doerflinger Y, Houben R, Becker JC, Schrama D, Weiss C, Goebeler M, Helmbold P, Goerdt S, Peitsch WK (2012) P-cadherin expression in Merkel cell carcinomas is associated with prolonged recurrence-free survival. Br J Dermatol 166:1043-1052

Vogl AW, Pfeiffer DC, Redenbach DM, Grove BD (1993) Sertoli cell cytoskeleton. In: Russel LD, Griswold MD (eds) The Sertoli cell. Cache River Press, Clearwater, pp 39-86

von Bülow M, Heid H, Hess H, Franke WW (1995) Molecular nature of calicin, a major basic protein of the mammalian sperm head cytoskeleton. Exp Cell Res 219:407-413

Wehrens XH, Mies B, Gimona M, Ramaekers FC, Van Eys GJ, Small JV (1997) Localization of smoothelin in avian smooth muscle and identification of a vascular-specific isoform. FEBS Lett 405:315-320

Wrobel KH, Mademann R, Sinowatz F (1979) The lamina propria of the bovine seminiferous tubule. Cell Tissue Res 202:357-377

Wu JC, Gregory CW, DePhilip RM (1993) P-cadherin and E-cadherin are co-expressed in MDCK cells. Biochem Biophys Res Commun 195: $1329-1335$

Wuchter P, Boda-Heggemann J, Straub BK, Grund C, Kuhn C, Krause U, Seckinger A, Peitsch WK, Spring H, Ho AD, Franke WW (2007) Processus and recessus adhaerentes: giant adherens cell junction systems connect and attract human mesenchymal stem cells. Cell Tissue Res 328:499-514

Yazama F, Esaki M, Sawada H (1997) Immunocytochemistry of extracellular matrix components in the rat seminiferous tubule: electron microscopic localization with improved methodology. Anat Rec 248:51-62

Zhu Q, Emanuele NV, Van Thiel DH (2004) Calponin is expressed by Sertoli cells within rat testes and is associated with actin-enriched cytoskeleton. Cell Tissue Res 316:243-253

\section{Comment}

As already mentioned in the first article of this series on cell differentiation processes in the mammalian testis (L.M. Domke et al. [2014] The cell-cell junctions of mammalian testes: I. The adhering junctions of the seminiferous tubule epithelium represent special differentiation structures. Cell Tissue Res 357:645-665), since half a century, there are severe scientific controversies in this field of research. Therefore, we have felt obliged in this publication to attach as electronic supplementary material (ESM) a compilation of special references, including controversial ones (special literature collections, SLCs, Nos. 1-7), as well as a cumulative list of all references mentioned in relation to the subject of the cell and molecular biology of testicular peritubular walls (ESM: Cumulative Literature Collection, CLC). 